\title{
Size-resolved measurement of the mixing state of soot in the megacity Beijing, China: diurnal cycle, aging and parameterization
}

\author{
Y. F. Cheng ${ }^{1,2,7}$, H. Su ${ }^{3}$, D. Rose $^{3}$, S. S. Gunthe ${ }^{3, *}$, M. Berghof ${ }^{2}$, B. Wehner ${ }^{2}$, P. Achtert ${ }^{2}$, A. Nowak ${ }^{2}$, N. Takegawa ${ }^{4}$, \\ Y. Kondo ${ }^{5}$, M. Shiraiwa ${ }^{3, *}$, Y. G. Gong ${ }^{6}$, M. Shao ${ }^{1}$, M. Hu ${ }^{1}$, T. Zhu ${ }^{1}$, Y. H. Zhang ${ }^{1}$, G. R. Carmichael ${ }^{7}$, \\ A. Wiedensohler ${ }^{2}$, M. O. Andreae ${ }^{3}$, and U. Pöschl ${ }^{3}$ \\ ${ }^{1}$ College of Environmental Sciences and Engineering, Peking University, Beijing 100871, China \\ ${ }^{2}$ Leibniz Institute for Tropospheric Research, Leipzig 04318, Germany \\ ${ }^{3}$ Biogeochemistry Department, Max Planck Institute for Chemistry, Mainz 55020, Germany \\ ${ }^{4}$ Research Center for Advanced Science and Technology, the University of Tokyo, Tokyo, Japan \\ ${ }^{5}$ Department of Earth and Planetary Science, Graduate School of Science, the University of Tokyo, Tokyo 1130033, Japan \\ ${ }^{6}$ Research Institute of Chemical Defence, Beijing 102205, China \\ ${ }^{7}$ Center for Global and Regional Environment Research, University of Iowa, IA 52242, USA \\ *now at: EWRE Division, Department of Civil Engineering, Indian Institute of Technology Madras, Chennai 600036, India \\ ** now at: Department of Chemical Engineering, California Institute of Technology, Pasadena, USA
}

Correspondence to: H. Su (h.su@mpic.de)

Received: 4 November 2011 - Published in Atmos. Chem. Phys. Discuss.: 7 December 2011

Revised: 19 April 2012 - Accepted: 4 May 2012 - Published: 22 May 2012

\begin{abstract}
Soot particles are the most efficient light absorbing aerosol species in the atmosphere, playing an important role as a driver of global warming. Their climate effects strongly depend on their mixing state, which significantly changes their light absorbing capability and cloud condensation nuclei (CCN) activity. Therefore, knowledge about the mixing state of soot and its aging mechanism becomes an important topic in the atmospheric sciences.

The size-resolved (30-320 nm diameter) mixing state of soot particles in polluted megacity air was measured at a suburban site (Yufa) during the CAREBeijing 2006 campaign in Beijing, using a volatility tandem differential mobility analyzer (VTDMA). Particles in this size range with non-volatile residuals at $300^{\circ} \mathrm{C}$ were considered to be soot particles. On average, the number fraction of internally mixed soot in total soot particles $\left(F_{\text {in }}\right)$, decreased from 0.80 to 0.57 when initial $D_{\mathrm{p}}$ increased from 30 to $320 \mathrm{~nm}$. Further analysis reveals that: (1) $F_{\text {in }}$ was well correlated with the aerosol hygroscopic mixing state measured by a CCN counter. More externally mixed soot particles were observed when particles showed more heterogeneous features with regard to hygroscopicity. (2) $F_{\text {in }}$ had pronounced diurnal cycles. For particles in the accumulation mode $\left(D_{\mathrm{p}}\right.$ at $\left.100-320 \mathrm{~nm}\right)$, largest $F_{\text {in }}$ were ob-
\end{abstract}

served at noon time, with "apparent" turnover rates $\left(k_{\mathrm{ex} \rightarrow \text { in }}\right)$ up to $7.8 \% \mathrm{~h}^{-1}$. (3) $F_{\text {in }}$ was subject to competing effects of both aging and emissions. While aging increases $F_{\text {in }}$ by converting externally mixed soot particles into internally mixed ones, emissions tend to reduce $F_{\text {in }}$ by emitting more fresh and externally mixed soot particles. Similar competing effects were also found with air mass age indicators. (4) Under the estimated emission intensities, actual turnover rates of soot $\left(k_{\mathrm{ex} \rightarrow \text { in }}\right)$ up to $20 \% \mathrm{~h}^{-1}$ were derived, which showed a pronounced diurnal cycle peaking around noon time. This result confirms that (soot) particles are undergoing fast aging/coating with the existing high levels of condensable vapors in the megacity Beijing. (5) Diurnal cycles of $F_{\text {in }}$ were different between Aitken and accumulation mode particles, which could be explained by the faster growth of smaller Aitken mode particles into larger size bins.

To improve the $F_{\text {in }}$ prediction in regional/global models, we suggest parameterizing $F_{\text {in }}$ by an air mass aging indicator, i.e., $F_{\text {in }}=a+b x$, where $a$ and $b$ are empirical coefficients determined from observations, and $x$ is the value of an air mass age indicator. At the Yufa site in the North China Plain, fitted coefficients $(a, b)$ were determined as $(0.57$, $0.21),(0.47,0.21)$, and $(0.52,0.0088)$ for $x$ (indicators) 
as $\left[\mathrm{NO}_{\mathrm{z}}\right] /\left[\mathrm{NO}_{\mathrm{y}}\right],[\mathrm{E}] /[\mathrm{X}]$ ([ethylbenzene $] /[\mathrm{m}, \mathrm{p}$-xylene $]$ ) and $([\mathrm{IM}]+[\mathrm{OM}]) /[\mathrm{EC}]([$ inorganic + organic matter $] /[$ elemental carbon]), respectively. Such a parameterization consumes little additional computing time, but yields a more realistic description of $F_{\text {in }}$ compared with the simple treatment of soot mixing state in regional/global models.

\section{Introduction}

Soot particles are generally regarded as the most efficient light absorbing component of atmospheric aerosols (Rosen et al., 1979; Japar et al., 1986; Horvath, 1993; Bergstrom et al., 2007). They are produced by incomplete combustion of fossil fuel and biomass and they consist mainly of black or elemental carbon but may also contain some refractory organic matter (Horvath, 1993; Smith and O'Dowd, 1996; Burtscher et al., 2001; Novakov et al., 2003; Pöschl, 2005; Sadezky et al., 2005; Andreae and Gelencsér, 2006; Kondo et al., 2006, 2010; Rose et al., 2006; Frey et al., 2008; Cheng et al., 2009; Wehner et al., 2009). In the atmospheric science literature, the terms black carbon (BC), elemental carbon (EC), pyrogenic carbon are frequently used as synonyms for soot (e.g., Kondo et al., 2006, 2009; Pöschl et al., 2010). More discussion on this topic can be found in Andreae and Gelencsér (2006).

Soot particles, after emission, generally undergo aging processes by condensation (Smith et al., 1989), coagulation (Riemer et al., 2004, and references therein), as well as oxidation (Ivleva et al., 2007) and cloud/fog processing; and gradually become internally mixed (coated) with other chemical compounds. Depending on their mixing state, soot particles can be classified as internally mixed (coated) or externally mixed (uncoated). The mixing state of soot particles has a great influence on their climate effects. The light absorbing capability of soot (related to its direct radiative effects) can be enhanced by a factor of 1.5 to 3 when soot is coated by or internally mixed with other aerosol components including sulfate, nitrate, organics and water (Jacobson, 2000; Lesins et al., 2002; Bond et al., 2006; Cheng et al., 2006, 2008a, b, 2009; Shiraiwa et al., 2008, 2010). Moreover, the coating of soot particles can significantly enhance their ability to be activated as cloud condensation nuclei (CCN) (Rose et al., 2011) and hence influence cloud formation processes (related to their indirect radiative effects) and the removal of soot particles from the atmosphere. For these reasons, the mixing state is a crucial parameter for soot particles, uncertainty about which has made it difficult to accurately assess its climatic impact (Jacobson, 2001).

In global/regional climate models, the turnover rate $\left(k_{\mathrm{ex} \rightarrow \text { in }}\right)$ is used to describe the conversion rate of externally mixed to internally mixed soot particles. Due to limited knowledge and computational limits, a constant $k_{\text {ex } \rightarrow \text { in }}$ was assumed in most studies, varying from 1.25 to
$2.5 \% \mathrm{~h}^{-1}$ (Cooke and Wilson, 1996; Cooke et al., 1999, 2002; Lohmann et al., 2000; Jacobson, 2001; Koch, 2001). To obtain a more realistic $k_{\mathrm{ex} \rightarrow \mathrm{in}}$, several aerosol modeling studies have been carried out to examine quantitatively $k_{\text {ex } \rightarrow \text { in }}$ of soot particles (Riemer et al., 2004, 2010). However, it is challenging to validate the modeling results against atmospheric conditions, since modeling of the soot mixing state is almost equivalent to modeling all physico-chemical processes in the gas and aerosol phases.

Decades ago, information about the soot mixing state relied on particle morphology measurements by Transmission Electron Microscopy (Katrinak et al., 1992, 1993; Hasegawa and Ohta, 2002). This technique does not always give reliable information, as volatile coatings may be lost, or thin coatings may not be evident. Later on, several online instruments with high time resolution were developed, i.e., volatility tandem differential mobility analyzer (VTDMA) (Philippin et al., 2004), single particle soot photometer (SP2) (Stephens et al., 2003) and aerosol time-of-flight mass spectrometer (ATOFMS) (Moffet and Prather, 2009). Among these methods, only the VTDMA is able to detect particle smaller than $0.1 \mu \mathrm{m}$. Based on these online methods, several field studies have been carried out in recent years at regional (Engler et al., 2007), suburban (Shiraiwa et al., 2007; Cheng et al., 2009; Wehner et al., 2009), and urban sites (Rose et al., 2006), and by aircraft measurements (Moteki et al., 2007). The aging of soot particles was found to be well correlated with several air mass age indicators, e.g., ratios of $\mathrm{C}_{2} \mathrm{H}_{4}$ to $\mathrm{C}_{2} \mathrm{H}_{2}$ (Moteki et al., 2007), 2-pentyl nitrate $\left(2-\mathrm{PeONO}_{2}\right)$ to $n$-pentane $(n$ $\mathrm{C}_{5} \mathrm{H}_{12}$ ) (Shiraiwa et al., 2007) and OC to EC (organic carbon/elemental carbon) (Cheng et al., 2006). Under certain assumptions on the air mass history and $\mathrm{OH}$ concentrations, rates of change of $F_{\text {in }}$ (number fraction of internally mixed soot particles) around 1 to $2.3 \% \mathrm{~h}^{-1}$ were derived (Moteki et al., 2007; Shiraiwa et al., 2007).

In the summer of 2006, measurements of the mixing state of non-volatile particles (here taken to be "soot particles", see discussion in Sect. 2.2) were carried out at a suburban site of Beijing in the North China Plain by using a VTDMA (Cheng et al., 2009; Wehner et al., 2009). In this study, we perform an in-depth analysis of VTDMA results, focusing on the following topics: (1) comparison of the mixing state of soot measured by a VTDMA and the aerosol hygroscopicity mixing state determined by a CCN (cloud condensation nuclei) counter; (2) diurnal variation and evolution of soot mixing state at different size ranges; (3) calculation of $k_{\mathrm{ex} \rightarrow \text { in }}$ and the influence of emissions on it; and (4) potential parameterization methods. 


\section{Methods}

\subsection{Overview of the campaign}

As part of the "Campaign of Air Quality Research in Beijing and Surrounding Region 2006" (CAREBeijing 2006), air pollutants including aerosol and gases were comprehensively measured at a suburban site, Yufa $\left(39.51467^{\circ} \mathrm{N}\right.$, $116.30533^{\circ} \mathrm{E}, \sim 25 \mathrm{~m}$ above ground level), during the summer of 2006. The Yufa site is located in the south of Beijing, roughly $50 \mathrm{~km}$ away from the urban center. One major road passes east of the measurement site, at a distance of less than $200 \mathrm{~m}$. Figure S1 (in the Supplement) shows the meteorological conditions at the Yufa site from 15 August to 9 September. During this period, the averages ( \pm one standard deviation) of temperature, relative humidity (RH) and wind speed were $26.2 \pm 3.7^{\circ} \mathrm{C}, 68 \pm 17 \%$ and $1.6 \pm 1.4 \mathrm{~m} \mathrm{~s}^{-1}$, respectively (based on 5-min resolution meteorological data, see Supplement Fig. S1).

\subsection{VTDMA measurement}

A volatility tandem differential mobility analyzer (VTDMA) (Orsini et al., 1996; Philippin et al., 2004) was used to measure the number size distributions of the non-volatile residuals of pre-selected mono-disperse particles that were heated at $300^{\circ} \mathrm{C}$ ( 7 selected particle diameters in the range of 30 to $320 \mathrm{~nm}$; time resolution of $1 \mathrm{~h}$ for a complete cycle of 7 diameters). In the thermal chamber (i.e., at $300^{\circ} \mathrm{C}$ ) of the VTDMA, the coating materials undergo volatilization leaving behind the non-volatile cores. Details about the VTDMA measurements at the Yufa site in 2006 can be found in Cheng et al. (2009) and Wehner et al. (2009). The volatilization results in a change of particle size, where unchanged particles indicate no coating material while big changes indicate a large fraction of coating materials. In continental polluted megacity air, the material of sub-micrometer particles that is non-volatile at this temperature (i.e., $300{ }^{\circ} \mathrm{C}$ ) is considered to be mostly "soot" (Smith and O'Dowd, 1996; Burtscher et al., 2001; Kondo et al., 2006, 2010; Rose et al., 2006; Frey et al., 2008; Cheng et al., 2009; Wehner et al., 2009), which consists mainly of black or elemental carbon but may also contain some refractory organic matter (Pöschl, 2005; Sadezky et al., 2005; Andreae and Gelencsér, 2006). Since the VTDMA actually measures non-volatile-core containing particles (NVP), the notation "soot (NVP)" was mostly used instead of "soot" when referring to the VTDMA results.

In VTDMA measurements, the size distribution of nonvolatile residuals is classified into three groups according to $D_{\mathrm{p}, 300^{\circ} \mathrm{C}} / D_{\mathrm{p}}$, where $D_{\mathrm{p}}$ is the initial diameter of the sampled dry particles and $D_{\mathrm{p}, 300^{\circ} \mathrm{C}}$ is the diameter of the particle residual after being heated at $300^{\circ} \mathrm{C}$. Following Wehner et al. (2009), (1) particles with $D_{\mathrm{p}, 300^{\circ} \mathrm{C}} / D_{\mathrm{p}}<$ $45 \%$ were denoted as "high-volatile" and not considered as soot particles; (2) particles with $45 \%<D_{\mathrm{p}, 300^{\circ} \mathrm{C}} / D_{\mathrm{p}}<$
$82 \%$ were denoted as "medium-volatile" and considered as internally mixed (coated) soot particles; and (3) Particles

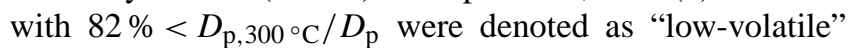
and considered as externally mixed (uncoated) soot particles.

$F_{\text {in }}$, the number fraction of internally mixed soot particles (among all soot-containing particles), was intensively used for discussion in this paper and calculated as,

$F_{\text {in }}=n_{\text {in }} /\left(n_{\text {in }}+n_{\text {ex }}\right)$

where $n_{\text {in }}$ is the number concentration of internally mixed soot (NVP) particles, and $n_{\mathrm{ex}}$ is the number concentration of externally mixed soot (NVP) particles.

\subsection{The turnover rate of soot particles}

The turnover rate, $k_{\mathrm{ex} \rightarrow \mathrm{in}}$, can be used to describe the conversion/aging rate of the externally mixed soot to internally mixed particles. It is defined as the rate of percentage change of externally mixed soot particles due to conversion/aging processes (Eq. 2).

$\left(\frac{\partial n_{\mathrm{ex}}}{\partial t}\right)_{\mathrm{ex} \rightarrow \mathrm{in}}=-k_{\mathrm{ex} \rightarrow \mathrm{in}} n_{\mathrm{ex}}$

where $\left(\partial n_{\mathrm{ex}} / \partial t\right)_{\mathrm{ex} \rightarrow \text { in }}$ is the rate of change of $n_{\mathrm{ex}}$ due to conversion/aging processes.

In case condensation dominates the conversion, $n_{\text {tot }}$, the number concentration of total $(\mathrm{ex}+\mathrm{in})$ soot particles can be considered as a constant. Dividing Eq. (2) by $n_{\text {tot }}$, we have

$\left(\frac{\partial F_{\text {in }}}{\partial t}\right)_{\mathrm{ex} \rightarrow \text { in }}=k_{\mathrm{ex} \rightarrow \mathrm{in}}\left(1-F_{\text {in }}\right)$

The $k_{\mathrm{ex} \rightarrow \text { in }}$, however, can't be directly solved by substituting $n_{\text {ex }}$ or $F_{\text {in }}$ obtained from field measurements into Eqs. (2) or (3). This is because the observed changes of $n_{\mathrm{ex}}$ and $F_{\text {in }}$ are subject to multiple processes in the atmosphere, including horizontal/vertical transport (subscribed by "Tran"), emissions (subscribed by "Emis"), deposition (subscribed by "Depo"), condensation (subscribed by "Cond") and coagulation (subscribed by "Coag") as in Eq. (4).

$$
\begin{aligned}
\frac{\partial F_{\text {in }}}{\partial t} & =\overbrace{\left(\frac{\partial F_{\text {in }}}{\partial t}\right)_{\text {Cond }}+\left(\frac{\partial F_{\text {in }}}{\partial t}\right)_{\text {Coag }}}^{\text {aging }(e x \rightarrow \text { in })}+\left(\frac{\partial F_{\text {in }}}{\partial t}\right)_{\text {Tran }} \\
& +\left(\frac{\partial F_{\text {in }}}{\partial t}\right)_{\text {Emis }}+\left(\frac{\partial F_{\text {in }}}{\partial t}\right)_{\text {Depo }}
\end{aligned}
$$

in which $F_{\text {in }}$ could also be replaced by $n_{\text {ex }}$ or $n_{\text {in }}$.

During daytime (the focus period of this study), the condensation dominates the aging processes, especially for relatively large particles (Jacobson, 1997; Riemer et al., 2004). The impact of transport and deposition on the fraction $F_{\text {in }}$ is also not prominent because both the internally and externally mixed soot particles undergo similar transport and deposition processes and their ratios are likely conserved ( $\mathrm{Su}$ 
et al., 2008; Wiedensohler et al., 2009). Therefore, we assume that $\partial F_{\text {in }} / \partial t$ is mainly controlled by the condensational aging process ("Cond") and emissions ("Emis") while other processes are supposed to be unimportant and not considered in this study.

When the emission term in Eq. (4) is also neglected, an "apparent" turnover rate can be determined by $k_{\mathrm{ex} \rightarrow \text { in }}=$ $\left(\Delta F_{\text {in }} / \Delta t\right) /\left(1-F_{\text {in }}\right)$, which attributes all variations in $F_{\text {in }}$ to an "apparent" conversion process. In previous studies, "apparent" $k_{\mathrm{ex} \rightarrow \text { in }}$ of $1.3-5.8 \% \mathrm{~h}^{-1}$ has been reported, corresponding to $\left(\Delta F_{\text {in }} / \Delta t\right)$ of $1.0-2.3 \% \mathrm{~h}^{-1}$ and $F_{\text {in }}$ of $0.2-0.6$ (Moteki et al., 2007; Shiraiwa et al., 2007).

\subsection{CCN measurement and hygroscopicity $(\kappa)$ distribution}

Size-resolved CCN efficiency spectra (activation curves) were measured with a Droplet Measurement Technologies continuous flow CCN counter (DMT-CCNC) coupled to a differential mobility analyzer (DMA; TSI 3071) and a condensation particle counter (CPC; TSI 3762). The CCNC was operated at a total flow rate of $0.51 \mathrm{~min}^{-1}$ with a sheath-toaerosol flow ratio of 10 . The effective water vapor supersaturation $(S)$ was regulated by the temperature difference between the upper and lower end of the CCNC flow column $(\Delta T)$ and calibrated with ammonium sulfate aerosol as described by Rose et al. (2008).

For each CCN measurement cycle, $\Delta T$ was set to 5 different levels $(2.0-11.9 \mathrm{~K})$ corresponding to $S$ values in the range of $0.07-0.86 \%$. For each $\Delta T$ and the respective $S$, the diameter of the dry aerosol particles selected by the DMA $\left(D_{\mathrm{p}}\right)$ was set to 9 different values in the range of 20-290 nm depending on the supersaturation selected. At each $D_{\mathrm{p}}$, the number concentration of total aerosol particles (condensation nuclei, $\mathrm{CN}$ ), $N_{\mathrm{CN}}$ was measured with the $\mathrm{CPC}$, and the number concentration of $\mathrm{CCN}, N_{\mathrm{CCN}}$, was measured with the CCNC. The integration time for each measurement data point was $30 \mathrm{~s}$, the recording of a $\mathrm{CCN}$ efficiency spectrum took $\sim 16$ min (including a $50 \mathrm{~s}$ adjustment time for each new particle size and $4 \mathrm{~min}$ for adjustment to the next supersaturation level), and the completion of a full measurement cycle comprising $\mathrm{CCN}$ efficiency spectra at 5 different supersaturation levels took $\sim 85 \mathrm{~min}$ (including $5 \mathrm{~min}$ of settling time for the changeover from highest to lowest $S$ ). For a detailed description of CCN measurements in the campaign, see Gunthe et al. (2011).

Size-resolved CCN efficiency spectra can be used to derive the cumulative distribution function of particle hygroscopicity, $H\left(\kappa, D_{\mathrm{p}}\right)$, which is defined as the number fraction of particles with a given dry diameter, $D_{\mathrm{p}}$, and with an effective hygroscopicity parameter smaller than the parameter $\kappa$ (Petters and Kreidenweis, 2007; Su et al., 2010). The data pair of $D_{\mathrm{p}}$ and $N_{\mathrm{CCN}} / N_{\mathrm{CN}}$ in a CCN spectrum can be converted to a corresponding data pair of $\kappa$ and $H\left(\kappa, D_{\mathrm{p}}\right)$ by solving the

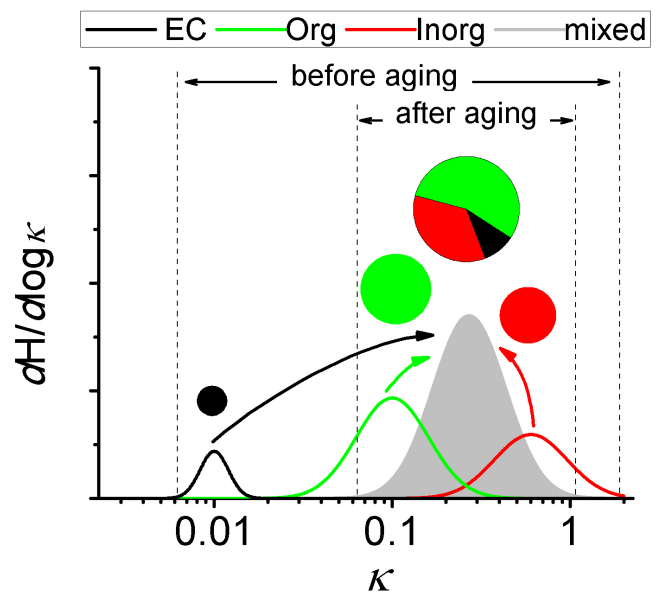

Fig. 1. Evolution of the mixing state and hygroscopicity $(\kappa)$ in the aging process. Solid lines refer to $\mathrm{d} H / \mathrm{d} \log \kappa$, the normalized number distributions of particle hygroscopicity. The areas of the pie diagrams refer to the abundance of individual chemical components (EC: elemental carbon, Org: organics, Inorg: inorganics). After aging, the externally mixed particles become internally mixed (coated).

$\kappa$-Köhler model equation (refer to Eqs. (21) and (22) in Su et al., 2010).

By fitting $H\left(\kappa, D_{\mathrm{p}}\right)$ with a cumulative single-mode lognormal distribution function, the following parameters were calculated: $\bar{\kappa}_{\mathrm{g}}$, the geometric mean of $\kappa$ in the fitted mode; and $\sigma_{\kappa, \mathrm{g}}$, the geometric standard deviation of $\kappa$ in the fitted mode. The spread of the $\kappa$ distribution, e.g., $\sigma_{\kappa, \mathrm{g}}$, reflects the mixing state of aerosols: under internally mixed conditions, all particles have the same composition and a uniform hygroscopicity mode, while under externally mixed conditions, particles can have distinct hygroscopicity modes (see Fig. 1).

\subsection{Air mass age indicator}

The aging of soot particles results in a change of their mixing state, i.e., conversion of externally mixed to internally mixed soot. An aged air mass has a larger fraction of internally mixed soot than a fresh air mass. Therefore, correlations can be expected between an air mass age indicator and the soot mixing state parameter (e.g., $F_{\text {in }}$ ). If such a correlation is significant, the soot mixing state could be parameterized by the air mass age indicators.

The age of air mass is a concept under the Lagrangian system. Ideally, the most fresh air mass is assigned an age of zero and its age will increase as the air mass becomes aged. The longer the air mass travels in the atmosphere, the older it will be. However, this does not mean that the age of an air mass can become infinitely large as injection of fresh emissions into the air mass would reduce its age.

To quantify air mass ages, several indicators have been proposed. They are based on the fact that the aging will change the chemical compositions of air masses. So 
Table 1. Statistics of $F_{\text {in }}$ at different diameters (429 data points).

\begin{tabular}{llllllll}
\hline$F_{\text {in }}$ & $30 \mathrm{~nm}$ & $50 \mathrm{~nm}$ & $100 \mathrm{~nm}$ & $150 \mathrm{~nm}$ & $200 \mathrm{~nm}$ & $260 \mathrm{~nm}$ & $320 \mathrm{~nm}$ \\
\hline Arithmetic mean & 0.80 & 0.74 & 0.70 & 0.64 & 0.60 & 0.62 & 0.57 \\
Standard deviation & 0.075 & 0.078 & 0.084 & 0.090 & 0.100 & 0.100 & 0.102 \\
\hline
\end{tabular}

parameters reflecting such changes can indicate the aging stage. Three indicators were used in this study.

$\left[\mathrm{NO}_{\mathrm{z}}\right] /\left[\mathrm{NO}_{\mathrm{y}}\right]$

In a fresh air mass from combustion sources, $\mathrm{NO}_{\mathrm{x}}$ $\left(\mathrm{NO}_{\mathrm{x}}=\mathrm{NO}+\mathrm{NO}_{2}\right)$ are the dominant components of $\mathrm{NO}_{\mathrm{y}}$ (the total odd nitrogen compounds in the atmosphere). As photochemical reactions proceed, $\mathrm{NO}_{\mathrm{x}}$ evolves to other $\mathrm{N}$ containing compounds such as $\mathrm{HNO}_{3}$ and PAN, and the ratio of $\left[\mathrm{NO}_{\mathrm{z}}\right] /\left[\mathrm{NO}_{\mathrm{y}}\right]\left(\mathrm{NO}_{\mathrm{z}}=\mathrm{NO}_{\mathrm{y}}-\mathrm{NO}_{\mathrm{x}}\right)$ will increase (Parrish et al., 1992; O'Brien et al., 1997). In this study, the nitrogen oxides $\left(\mathrm{NO}_{\mathrm{x}}\right)$ and total reactive nitrogen $\left(\mathrm{NO}_{\mathrm{y}}\right)$ were measured using a $\mathrm{NO}-\mathrm{O}_{3}$ chemiluminescence detector combined with a photolytic converter and a gold tube catalytic converter (Takegawa et al., 2006)

\section{$[\mathrm{E}] /[\mathrm{X}]$}

The ratios of hydrocarbons have been used as measures of photochemical age since Calvert (1976). Different reactivities of hydrocarbons result in different removal rates and monotonic change of their ratios in the aging process. We used the ratio of ethylbenzene and m,p-xylene ([E]/[X]) in this study. Ethylbenzene and m,p-xylene were measured by an online GC-PID (gas chromatograph-photo ionization detector) system, as detailed by Xie et al. (2008).

$([\mathrm{IM}]+[\mathrm{OM}]) /[\mathrm{EC}]$

As an air mass ages, more secondary aerosol is produced, which reduces the mass fraction of soot particles. $([\mathrm{IM}]+[\mathrm{OM}]) /([\mathrm{EC}])$ could hence be used as an indicator (Cheng et al., 2006), in which $[\mathrm{IM}]=\left[\mathrm{NH}_{4}^{+}\right]+\left[\mathrm{NO}_{3}^{-}\right]+\left[\mathrm{SO}_{4}^{2-}\right]+\left[\mathrm{Cl}^{-}\right]$(inorganic ions in $\mathrm{PM}_{1}$ measured by aerosol mass spectrometer, AMS) and $[\mathrm{OM}]$ was the organic matter mass (in $\mathrm{PM}_{1}$ ) determined by AMS. An online Sunset EC/OC analyzer was used to measure the mass concentrations of EC, [EC]. Details about the EC/OC analyzer and AMS can be found in Takegawa et al. (2009).

\section{Results and discussion}

\subsection{The mixing state of soot and hygroscopicity}

Table 1 summarizes statistics of $F_{\text {in }}$ measurements from this

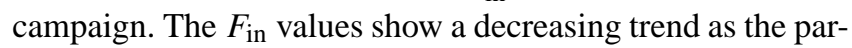
ticle size $D_{\mathrm{p}}$ increases, ranging from an $\overline{F_{\text {in }}}$ of $0.80 \pm 0.075$

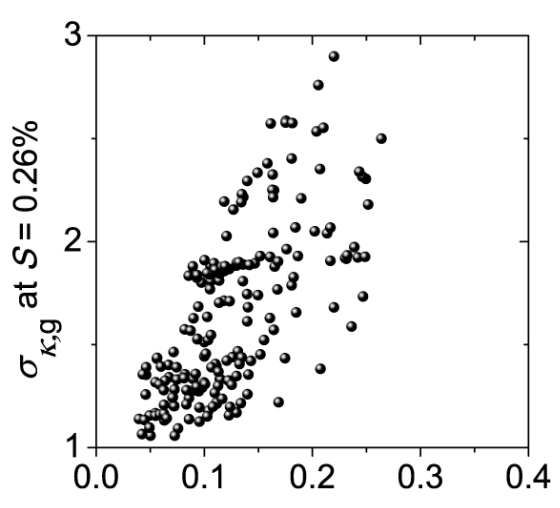

a) $1-F_{\text {in }}$ at $100 \mathrm{~nm}$

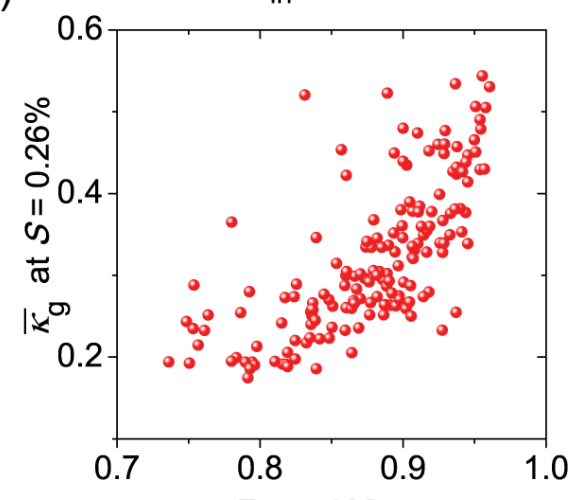

b) $F_{\text {in }}$ at $100 \mathrm{~nm}$

Fig. 2. Comparison of aerosol hygroscopicity and soot (NVP) mixing state parameters during the CAREBeijing-2006 campaign. The parameters $\bar{\kappa}_{\mathrm{g}}$ and $\sigma_{\kappa, \mathrm{g}}$ were calculated from the aerosol hygroscopicity (i.e., $\kappa$ ) distribution measured at supersaturation $S=0.26 \%$ (Su et al., 2010); and $F_{\text {in }}$ was determined for particles of diameters at $100 \mathrm{~nm}$ by the VTDMA measurements. Note that the mean activation diameter observed at $S=0.26 \%$ is $85 \mathrm{~nm}$ (Gunthe et al., 2011).

at $D_{\mathrm{p}}=30 \mathrm{~nm}$ to $\overline{F_{\text {in }}}$ of $0.57 \pm 0.102$ at $D_{\mathrm{p}}=320 \mathrm{~nm}$ (arithmetic mean \pm standard deviation). Figure 2 shows a comparison of hourly $F_{\text {in }}$ data with $\sigma_{\kappa, \mathrm{g}}$ (the geometric standard deviation in a lognormal $\kappa$ distribution, as detailed in Sect. 2.4., and $\mathrm{Su}$ et al., 2010). The $\left(1-F_{\text {in }}\right)$ is the number fraction of externally mixed soot (NVP) particles. The two parameters, $\sigma_{\kappa, \mathrm{g}}$ and $\left(1-F_{\text {in }}\right)$, are well correlated. This means that more externally mixed soot (NVP) particles were observed when particles showed more heterogeneous features in their hygroscopicity distributions (large $\sigma_{\kappa, \mathrm{g}}$ ). Such consistency gives 


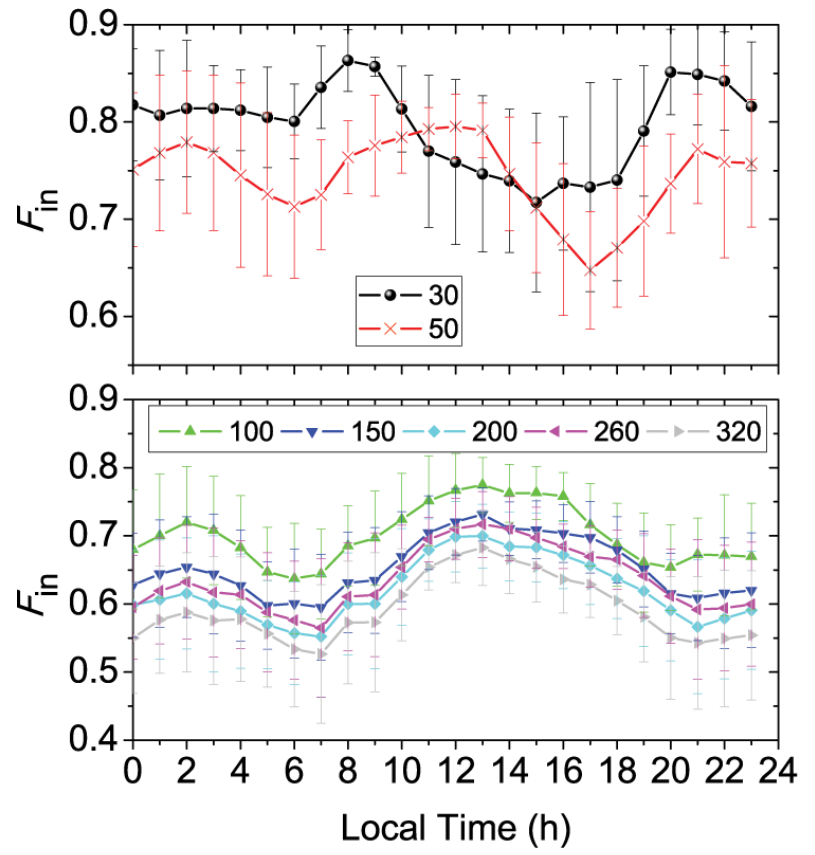

Fig. 3. Average diurnal variation of $F_{\text {in }}$ at different size bins (30, $50,100,150,200,260$, and $320 \mathrm{~nm}$ ). Symbols represent arithmetic mean values and error bars represent the standard deviation. Since transport might significantly affect the evolution of $F_{\text {in }}$, days with average wind speed $>2 \mathrm{~ms}^{-1}(20,22$ August, 3, 4, 5, 6 and 8 September) were completely removed from the statistics.

confidence about the robustness of both parameters and the reliability of the measuring systems.

During the CAREBeijing campaign, positive correlation between hourly $\bar{\kappa}_{\mathrm{g}}$ and $F_{\text {in }}$ was also found (Fig. $2 \mathrm{~b}$ ) as a result of their concurrent increase during the aging process. The increased $\bar{\kappa}_{\mathrm{g}}$ can be attributed to the increase of fraction of inorganic matter (IM) in aerosol particles. The IM is in general more hygroscopic and $\mathrm{CCN}$-active than the rest of the aerosol chemical species (Pöschl, 2011; Rose et al., 2011). The increase of IM fraction leads to a corresponding increase of the overall aerosol hygroscopicity and hence $\bar{\kappa}_{\mathrm{g}}$, which represents an averaged hygroscopicity of aerosols ( $\mathrm{Su}$ et al., 2010).

\subsection{Diurnal cycle of the soot mixing state}

Figure 3 shows a pronounced diurnal cycle of $F_{\text {in }}$, which also has a strong size dependence. For accumulation mode particles (i.e., $100 \mathrm{~nm}$ to $320 \mathrm{~nm}$, Fig. 3b), similar diurnal profiles of $F_{\text {in }}$ can be found, with a maximum at $\sim 13: 00 \mathrm{LT}$ (local time) and two minimums, in the early morning $\sim 07: 00 \mathrm{LT}$ and at night $\sim 21: 00 \mathrm{LT}$, respectively. As the day progresses, an increase in $F_{\text {in }}(08: 00-13: 00 \mathrm{LT})$ is observed for accumulation mode particles with "apparent" turnover rates of 6.7$7.8 \% \mathrm{~h}^{-1}$.
Table 2. Correlation matrix of $F_{\text {in }}$ at different diameters (429 data points).

\begin{tabular}{lrccccc}
\hline \multicolumn{1}{l}{$R$} & $30 \mathrm{~nm}$ & $50 \mathrm{~nm}$ & $100 \mathrm{~nm}$ & $150 \mathrm{~nm}$ & $200 \mathrm{~nm}$ & $260 \mathrm{~nm}$ \\
\hline $50 \mathrm{~nm}$ & 0.49 & & & & & \\
$100 \mathrm{~nm}$ & -0.12 & 0.40 & & & & \\
$150 \mathrm{~nm}$ & -0.09 & 0.25 & 0.86 & & & \\
$200 \mathrm{~nm}$ & -0.04 & 0.24 & 0.73 & 0.93 & & \\
$260 \mathrm{~nm}$ & -0.01 & 0.24 & 0.65 & 0.87 & 0.95 & \\
$320 \mathrm{~nm}$ & 0.00 & 0.28 & 0.58 & 0.80 & 0.89 & 0.94 \\
\hline
\end{tabular}

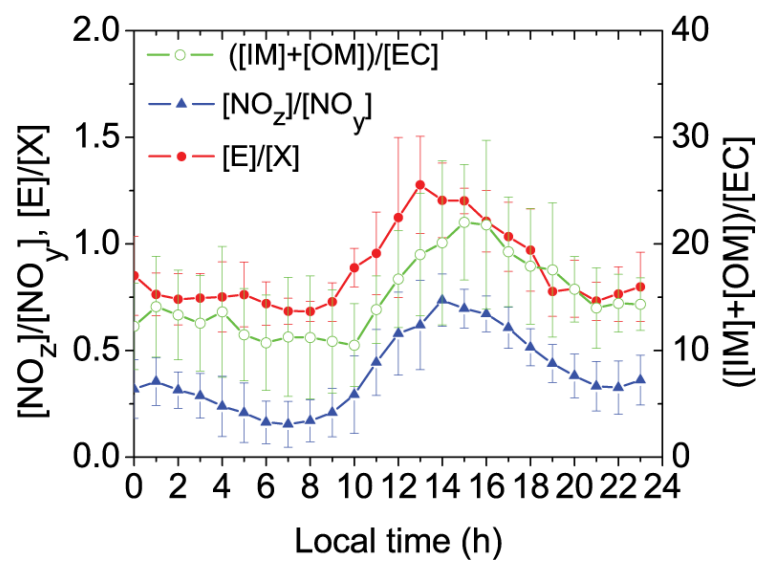

Fig. 4. Averaged diurnal variation of $\left[\mathrm{NO}_{\mathrm{z}}\right] /\left[\mathrm{NO}_{\mathrm{y}}\right],[\mathrm{E}] /[\mathrm{X}]$ and $([\mathrm{IM}]+[\mathrm{OM}]) /[\mathrm{EC}]$. Symbols represent arithmetic mean values and error bars represent the standard deviation.

In the Aitken mode, however, the variation of $F_{\text {in }}$ is different to that in the accumulation mode (Fig. 3a). The maximum of $F_{\text {in }}$ appears earlier at $\sim 08: 00 \mathrm{LT}$ (at $D_{\mathrm{p}}=30 \mathrm{~nm}$ ) and 12:00 LT (at $D_{\mathrm{p}}=50 \mathrm{~nm}$ ), and the afternoon minimum $F_{\text {in }}$ appears earlier as well. The distinct behaviors of Aitken mode particles are shown by the correlation matrix in Table 2, where $F_{\text {in }}$ of Aitken mode particles show poor correlations with the accumulation mode particles. The reasons for such correlations will be further discussed in Sect. 3.5.

For accumulation mode particles presented in Fig. $3 b, F_{\text {in }}$ shows a peak around noon time. Such a diurnal cycle indicates that ground-based measurements were subject to competing effects from physico-chemical aging and the introduction of fresh emissions. While the aging increases $F_{\text {in }}$ by turning externally mixed particles into internally mixed ones, the fresh emissions, with low $F_{\text {in }}$, tend to reduce the $F_{\text {in }}$ values. Similar competing effects can also be found in the diurnal courses of the air mass age indicators (e.g., $\left[\mathrm{NO}_{\mathrm{z}}\right] /\left[\mathrm{NO}_{\mathrm{y}}\right]$, $[\mathrm{E}] /[\mathrm{X}]$ and $([\mathrm{IM}]+[\mathrm{OM}]) /[\mathrm{EC}]$ in Fig. 4) and aerosol single scattering albedo as reported in Garland et al. (2008, 2009). 


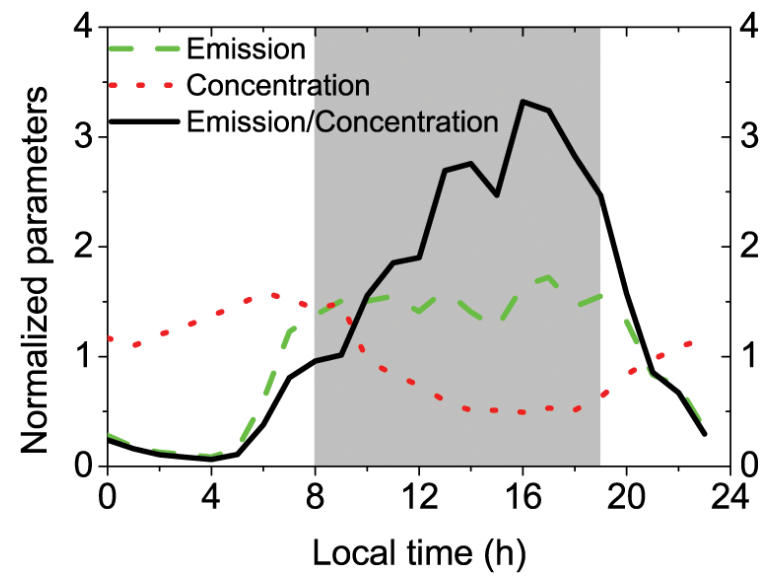

Fig. 5. Diurnal variation of normalized parameters: (a) emission rates of $\mathrm{EC},(\partial[\mathrm{EC}] / \partial t)_{\mathrm{Emis}}$, which is assumed the same as $\mathrm{CO}$ emission rates in Beijing (green dashed lines); (b) EC concentrations measured by an online Sunset EC/OC analyzer (red dotted lines); and (c) ratio of emission rate to EC concentration (black solid lines). All parameters are normalized by their diurnal means, respectively. Shaded areas represent the time period of 08:0019:00 LT when vertical mixing is supposed to significantly affect EC concentrations.

\subsection{Estimation of soot emission rate}

Emissions have a significant impact on the measured $F_{\text {in }}$ and the "apparent" $k_{\mathrm{ex} \rightarrow \text { in }}$ (soot turnover rate). Before determining the actual $k_{\mathrm{ex} \rightarrow \mathrm{in}}$, we need to first quantify the emissions.

The emission rate can be divided into a diurnal profile describing its relative variation and the absolute value of any point on this profile. In this study, we adopt the diurnal profile of $\mathrm{CO}$ (carbon monoxide) emissions in Beijing areas (Zhou et al., 2010) and assume that soot emissions have a similar diurnal pattern. Then measured EC loadings are used to estimate the absolute emission rate at certain period during night-time. With these two kinds of information, the whole emission profile can be quantified.

Note that the emission rate is often expressed as a flux in mass per area per time while its impact on EC concentrations, $(\partial[\mathrm{EC}] / \partial t)_{\text {Emis }}$, has a unit of mass per volume per time. From the aspect of Eulerian grid models, the diurnal profile (relative variation) of the emission flux and $(\partial[\mathrm{EC}] / \partial t)_{\mathrm{Emis}}$ is the same while their absolute values differ by a factor of the grid height.

Figure 5 shows the diurnal profile of the emission rate $(\partial[\mathrm{EC}] / \partial t)_{\text {Emis }}$ used in this study. To estimate its absolute values, we tried to find a time period when the concentration variation is dominated by emissions, i.e., $\partial[\mathrm{EC}] / \partial t \approx$ $(\partial[\mathrm{EC}] / \partial t)_{\text {Emis. }}$. The EC concentration is also shown in Fig. 5. It is clear that $[E C]$ is not always increasing though $(\partial[\mathrm{EC}] / \partial t)_{\text {Emis }}$ is always positive. This is because transport plays an important role on the diurnal variation of [EC].
To minimize the impact of transport and obtain an optimal estimate on absolute values of $(\partial[\mathrm{EC}] / \partial t)_{\text {Emis }}$, we take the following criteria, eliminating days with average wind speed $>2 \mathrm{~m} \mathrm{~s}^{-1}$ (20, 22 August, 3, 4, 5, 6 and 8 September), excluding time periods with strong vertical mixing (from 08:00 to 19:00 LT), and choosing periods with largest ratio of normalized $(\partial[\mathrm{EC}] / \partial t)_{\text {Emis }}$ to $[\mathrm{EC}]$ (at 20:00 LT). The reason for choosing low wind speeds and night-time periods is to minimize the impact of horizontal and vertical transport processes on $[\mathrm{EC}]$. Large ratios of $(\partial[\mathrm{EC}] / \partial t)_{\mathrm{Emis}} /[\mathrm{EC}]$ ensures that the emission term dominates the variation of [EC].

Finally, $\Delta[E C] / \Delta t$ at 20:00 $\left(\sim 0.89 \mu \mathrm{g} \mathrm{m}^{-3} \mathrm{~h}^{-1}\right)$ was taken as an optimal estimation of $(\partial[\mathrm{EC}] / \partial t)_{\text {Emis }}$ at 20:00. It was then used to calculate $(\partial[\mathrm{EC}] / \partial t)_{\mathrm{Emis}}$ for the rest of the day by applying the diurnal profile in Fig. 5. Table 3 summarizes the diurnal variation of the measured [EC] and the calculated $(\partial[\mathrm{EC}] / \partial t)_{\text {Emis }}$. The mean emission rate is $\sim 13 \%$ of the mean soot concentration per hour $\left(13 \% \mathrm{~h}^{-1}\right)$.

\subsection{Actual turnover rate of soot}

In this section, a conceptual model is used to analyze the observed variation of $F_{\text {in }}$. Since $F_{\text {in }}$ of particles of all sizes in the accumulation mode (i.e., $100-320 \mathrm{~nm}$ ) showed similar behaviors, $F_{\text {in }}$ at $150 \mathrm{~nm}$ is taken as an example and will be discussed through this section.

Two processes are considered in the model: emissions and the condensational aging process that converts equal amounts of externally mixed particles into internally mixed particles. We also assume that all (or most) particles stay in the same size bin after the 1-h aging process. This assumption, to a large extent, simplifies the following analysis, and could at least be valid for a broader size bracket, e.g., $[100 \mathrm{~nm}$, $350 \mathrm{~nm}]$. The transport and dry deposition processes are supposed not to significantly change $F_{\text {in }}$ (assuming $n_{\text {in }}$ and $n_{\text {ex }}$ have the same gradient and dry deposition velocity) and are therefore ignored in this analysis.

Then the variation of $F_{\text {in }}$ in the time interval $\Delta t$ can be derived by Eq. (5):

$$
\begin{aligned}
\Delta F_{\mathrm{in}}= & \frac{n_{\mathrm{in}}+\left(\frac{\partial n_{\mathrm{in}}}{\partial t}\right)_{\mathrm{ex} \rightarrow \mathrm{in}}+\left(\frac{\partial n_{\mathrm{in}}}{\partial t}\right)_{\mathrm{Emis}}}{n_{\mathrm{tot}}+\left(\frac{\partial n_{\text {tot }}}{\partial t}\right)_{\text {Emis }}}-F_{\mathrm{in}} \\
= & \frac{n_{\mathrm{in}}+k_{\mathrm{ex} \rightarrow \mathrm{in}} n_{\mathrm{ex}}+\beta\left(\frac{\partial n_{\mathrm{tot}}}{\partial t}\right)_{\mathrm{Emis}}}{n_{\mathrm{tot}}+\left(\frac{\partial n_{\mathrm{tot}}}{\partial t}\right)_{\text {Emis }}}-F_{\mathrm{in}}
\end{aligned}
$$

in which $\beta=\left(\partial n_{\text {in }} / \partial n_{\text {tot }}\right)_{\text {Emis }}$ is the fraction of internally mixed soot in emissions and is assumed to be a constant. The minimum $F_{\text {in }} \sim 0.6$ can be considered as the upper limit of $\beta$, and we also tested other $\beta$ values (0.2 and 0.4 ) for sensitivity studies. 
Table 3. Mean diurnal variation of $[E C]$ (EC concentrations) and $(\partial[E C] / \partial t)_{\text {Emis }}$ (emission rates).

\begin{tabular}{cccc|cccc}
\hline $\begin{array}{c}\text { Time } \\
\mathrm{h}\end{array}$ & $\begin{array}{c}{[\mathrm{EC}]} \\
\mu \mathrm{g} \mathrm{m}^{-3}\end{array}$ & $\begin{array}{c}(\partial[\mathrm{EC}] / \partial t)_{\text {Emis }} \\
\mu \mathrm{g} \mathrm{m}^{-3} \mathrm{~h}^{-1}\end{array}$ & $\begin{array}{c}\frac{(\partial[\mathrm{EC}] / \partial t)_{\text {Emis }}}{[\mathrm{EC}]} \\
\% \mathrm{~h}^{-1}\end{array}$ & $\begin{array}{c}\text { Time } \\
\mathrm{h}\end{array}$ & $\begin{array}{c}{[\mathrm{EC}]} \\
\mu \mathrm{g} \mathrm{m}^{-3}\end{array}$ & $\begin{array}{c}(\partial[\mathrm{EC}] / \partial t)_{\text {Emis }} \\
\mu \mathrm{g} \mathrm{m}^{-3} \mathrm{~h}^{-1}\end{array}$ & $\begin{array}{c}\frac{(\partial[\mathrm{EC}] / \partial t)_{\text {Emis }}}{[\mathrm{EC}]} \\
\% \mathrm{~h}^{-1}\end{array}$ \\
\hline 0 & 6.1 & 0.191 & 3.1 & 12 & 3.9 & 0.954 & 24.5 \\
1 & 5.8 & 0.120 & 2.1 & 13 & 3.1 & 1.092 & 35.2 \\
2 & 6.3 & 0.088 & 1.4 & 14 & 2.7 & 0.952 & 35.3 \\
3 & 6.7 & 0.074 & 1.1 & 15 & 2.7 & 0.856 & 31.7 \\
4 & 7.2 & 0.058 & 0.8 & 16 & 2.6 & 1.114 & 42.8 \\
5 & 7.7 & 0.108 & 1.4 & 17 & 2.8 & 1.168 & 41.7 \\
6 & 8.3 & 0.407 & 4.9 & 18 & 2.7 & 0.986 & 36.5 \\
7 & 8.0 & 0.832 & 10.4 & 19 & 3.3 & 1.052 & 31.9 \\
8 & 7.5 & 0.934 & 12.5 & 20 & 4.4 & 0.894 & 20.3 \\
9 & 7.8 & 1.022 & 13.1 & 21 & 5.1 & 0.564 & 11.1 \\
10 & 5.1 & 1.020 & 20.0 & 22 & 5.7 & 0.495 & 8.7 \\
11 & 4.4 & 1.052 & 23.9 & 23 & 6.1 & 0.232 & 3.8 \\
\hline
\end{tabular}

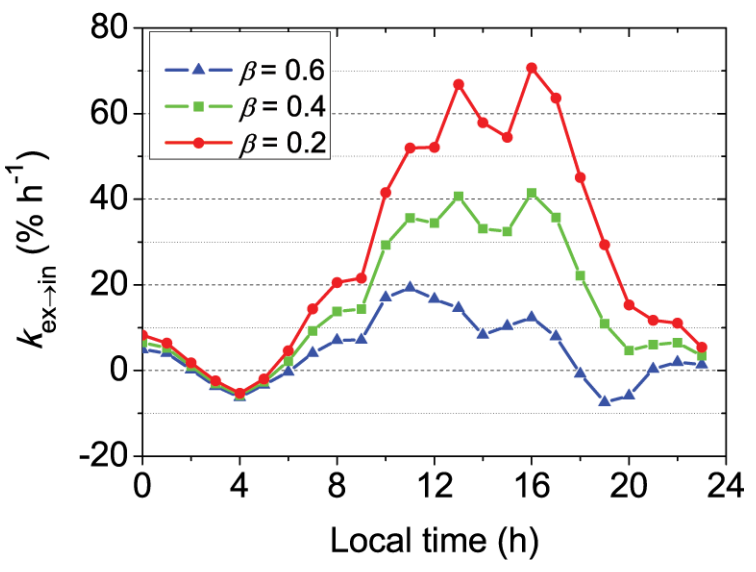

Fig. 6. The actual turnover rate of soot (NVP), $k_{\mathrm{ex} \rightarrow \text { in }}$, assuming different emission factors $\beta$ (number fraction of internally mixed soot particles to total soot particles in the emissions).

Dividing the numerator and fraction of the first term on the right-hand side of Eq. (5) by $n_{\text {tot }}$, we have

$$
\Delta F_{\text {in }}=\frac{F_{\text {in }}+k_{\mathrm{ex} \rightarrow \text { in }}\left(1-F_{\text {in }}\right)+\beta\left[\frac{1}{n_{\text {tot }}}\left(\frac{\partial n_{\text {tot }}}{\partial t}\right)_{\text {Emis }}\right]}{1+\left[\frac{1}{n_{\text {tot }}}\left(\frac{\partial n_{\text {tot }}}{\partial t}\right)_{\text {Emis }}\right]}-F_{\text {in }}
$$

Assuming $\frac{1}{n_{\text {tot }}}\left(\partial n_{\text {tot }} / \partial t\right)_{\text {Emis }}=\frac{1}{[\mathrm{EC}]}(\partial[\mathrm{EC}] / \partial t)_{\text {Emis }}($ see Table 3), $k_{\mathrm{ex} \rightarrow \text { in }}$ becomes the only unknown parameter and can be calculated by solving Eq. (6).

Figure 6 shows the diurnal cycles of campaign-averaged $k_{\mathrm{ex} \rightarrow \text { in }}$ calculated for particles at $150 \mathrm{~nm}$ with different $\beta$. Compared to a fixed $k_{\mathrm{ex} \rightarrow \text { in }}$ value commonly used in regional and global models, the observation-constrained $k_{\mathrm{ex} \rightarrow \text { in }}$ shows higher values with a maximum around 11:00-15:00 LT, and low values in the early morning and late afternoon. Such a diurnal cycle always holds, even after varying $(\partial[\mathrm{EC}] / \partial t)_{\text {Emis }}$ by a factor of two (see Fig. S2). The cycle of the turnover rate, $k_{\mathrm{ex} \rightarrow \mathrm{in}}$, supports previous results in modeling studies (Riemer et al., 2004, 2010), which show high daytime $k_{\mathrm{ex} \rightarrow \text { in }}$ dominated by condensation processes, and low $k_{\text {ex } \rightarrow \text { in }}$ resulting from both slower condensation and coagulation processes in the early morning and late afternoon. Although $k_{\mathrm{ex} \rightarrow \text { in }}$ for night-time periods are also presented in Fig. 6, these night-time values require caveats because the coagulation-induced aging could become more important than the condensation during night-time (Riemer et al., 2004, 2010 ), which violates our assumption on $k_{\mathrm{ex} \rightarrow \text { in }}$ calculations.

Since the condensation-induced turnover rate is proportional to the condensable vapor pressure, the derived daytime $k_{\mathrm{ex} \rightarrow \text { in }}$ implies a peak of condensable vapor pressure at the same period (11:00-15:00 LT). It is already known that gaseous sulfuric acid (precursor of sulfate in particles) often shows a peak around noon. Our results indicate that even the potentially present un-identified condensable vapors might have similar diurnal cycles as sulfuric acid. Instead of complete characterizations of these un-identified vapors, the similarity in their diurnal variations enables the use of a simple parameterization method as an alternative solution in aerosol modeling studies, as will be discussed below.

Due to the presence of primary emission sources, the actual turnover rate of soot, $k_{\mathrm{ex} \rightarrow \text { in }}$ is higher than the "apparent" $k_{\mathrm{ex} \rightarrow \text { in }}$. The freshly emitted particles contain more externally mixed soot than the aged ambient air. The observed "aging" of soot (NVP) is to a certain extent compensated by the fresh emissions, the extent of which depends on the emission intensity. For the estimated emission intensity, $\overline{(\partial[\mathrm{EC}] / \partial t)_{\mathrm{Emis}}} / \overline{[\mathrm{EC}]}$ of $13 \% \mathrm{~h}^{-1}$ and $\beta=0.6, k_{\mathrm{ex} \rightarrow \text { in }}$ values reached up to $20 \% \mathrm{~h}^{-1}$ (see Fig. 6), much faster than the "apparent" $k_{\mathrm{ex} \rightarrow \text { in }}$ of $6.7-7.8 \% \mathrm{~h}^{-1}$.

The aging process in Beijing is also much faster than $k_{\mathrm{ex} \rightarrow \text { in }}$ of $1.3-5.8 \% \mathrm{~h}^{-1}$ in previous field measurements (Moteki et al., 2007; Shiraiwa et al., 2007) and 1.25$2.5 \% \mathrm{~h}^{-1}$ in modeling studies (Cooke and Wilson, 1996; Cooke et al., 1999, 2002; Lohmann et al., 2000; Jacobson, 
2001; Koch, 2001; Tsigaridis and Kanakidou, 2003; Riemer et al., 2004). The fast turnover rate in the polluted megacity air is consistent with the observed rapid particle growth in the same area (Wiedensohler et al., 2009), both of which can be attributed to the fast formation and condensation of secondary aerosols in the megacity. The flow of soot particles from megacities influences the global background of soot to a large extent. If those soot particles are already coated or internally mixed in a very short time due to strong condensation, the background soot should be mostly internally mixed, as has been suggested by Andreae and Rosenfeld (2008).

Figure 6 also shows that the absolute value of $k_{\mathrm{ex} \rightarrow \text { in }}$ strongly depends on the choice of the emission factor $\beta$, while the relative variation of $k_{\mathrm{ex} \rightarrow \text { in }}$ does not. Smaller $\beta$ values (large fraction of externally mixed soot in emissions) require faster $k_{\mathrm{ex} \rightarrow \text { in }}$ to explain the observed $F_{\text {in }}$ variations. For example, $\beta=0.2$ requires $k_{\mathrm{ex} \rightarrow \text { in }}$ up to $70 \% \mathrm{~h}^{-1}$ to meet the observations. On the other hand, $k_{\mathrm{ex} \rightarrow \text { in }}$ up to $20 \% \mathrm{~h}^{-1}$ require a large $\beta=0.6$, which means that $60 \%$ of the emitted soot particles should have already been internally mixed when they arrive at the measurement site.

\subsection{Distinct diurnal variations of $\boldsymbol{F}_{\text {in }}$ for Aitken and accumulation mode particles}

In the conceptual model, we assume that particle growth will not lead to significant change in $n_{\text {tot }}$ and $n_{\text {ex }}$, which means no significant shift of the particle size distribution occurs over a short time. While such an assumption is valid for large particles in the accumulation mode (i.e., $>100 \mathrm{~nm}$ ), it might be violated by the faster growth of small particles (e.g., $30 \mathrm{~nm}$ ) in the Aitken mode, which was reflected by the different diurnal cycles of $F_{\text {in }}$ at smaller diameters (see Fig. 3).

To describe the rate of change of a particle size distribution $n\left(D_{\mathrm{p}}\right)$ resulting from condensation, we adopted a general condensation equation (Seinfeld and Pandis, 2006, pp. 591) in the form

$$
\frac{\partial n}{n \partial t}=-\frac{\partial}{n \partial D_{\mathrm{p}}}\left(n \frac{4 D M}{R T D_{\mathrm{p}} \rho_{\mathrm{p}}} f(K n, \alpha) P\right)
$$

where $n$ denotes the particle number concentration at $D_{\mathrm{p}}, M$ is the molecular weight for the condensable species, $D$ is its diffusion coefficient in air, $R$ is the molar gas constant, $T$ is the temperature (in Kelvin), $\rho_{\mathrm{p}}$ is the density of the particles, $P$ is the supersaturated vapor pressure of the condensable species, $K n$ is the Knudsen number $\left(K n=2 \lambda / D_{\mathrm{p}}\right), \lambda$ is the mean free path of the condensable species in air, and $\alpha$ is the accommodation coefficient of the condensable species. $f(K n, \alpha)$ is the correction due to non-continuum effects and imperfect surface accommodation and can be calculated by

$$
f(K n, \alpha)=\frac{0.75 \alpha(1+K n)}{K n^{2}+K n+0.283 K n \alpha+0.75 \alpha}
$$

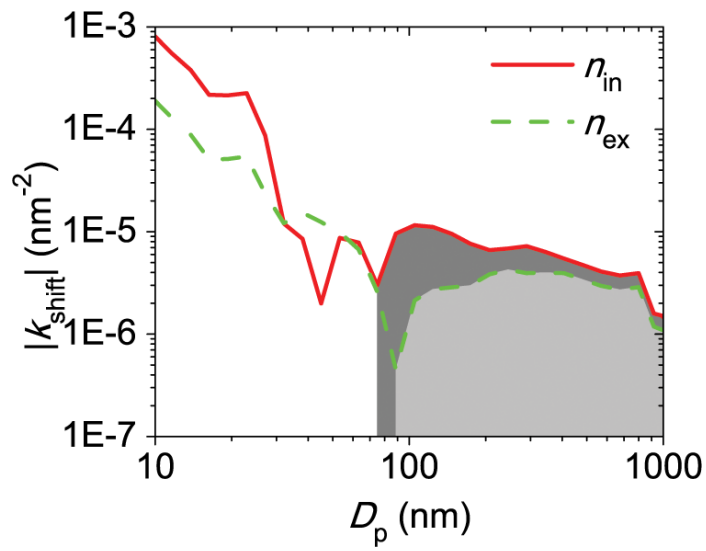

Fig. 7. The size dependence of the particle size distribution $n\left(D_{\mathrm{p}}\right)$ variation due to condensation growth. $k_{\text {shift }}$ equals $(\partial n / \partial t) / n$ due to condensation growth divided by a constant (in Eq. 20). $k_{\text {shift }}$ can either be positive or negative, which indicates increases and decreases of $n\left(D_{\mathrm{p}}\right)$ due to condensation growth, respectively. The shaded areas (with gray and light gray for $n_{\text {in }}$ and $n_{\text {ex }}$, respectively) indicate the size ranges where $k_{\text {shift }}$ are positive while $k_{\text {shift }}$ are negative in the un-shaded ranges.

Dividing both sides of Eq. (7) by $A=4 D M P /\left(R T \rho_{\mathrm{p}}\right)$, we get a parameter $k_{\text {shift }}$ :

$k_{\text {shift }}=\frac{1}{A} \frac{\partial n}{n \partial t}=-\frac{\partial}{n \partial D_{\mathrm{p}}}\left(\frac{n}{D_{\mathrm{p}}} f(K n, \alpha)\right)$

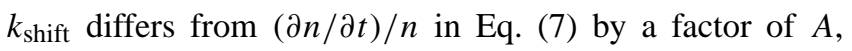
which is generally/mostly independent of particle sizes. So, $k_{\text {shift }}$ is equivalent to $(\partial n / \partial t) / n$ in representing the size dependence of the rate of change of $n$ due to condensation. By taking the measured $n\left(D_{\mathrm{p}}\right)$ and $\lambda=\lambda_{\text {air }}(298 \mathrm{~K}$, $1 \mathrm{~atm})=65.1 \mathrm{~nm}$ (Seinfeld and Pandis, 2006, p. 399), $k_{\text {shift }}$ can be calculated for each $D_{\mathrm{p}}$.

Figure 7 shows $k_{\text {shift }}$ as a function of the particle size $D_{\mathrm{p}}$, calculated with Eqs. (7)-(9) for the CAREBeijing 2006 campaign. The (mean) size distributions of the internally (externally) mixed soot (NVP) particles were used in the calculation (Wehner et al., 2009). Since VTDMA measurements covered only a limited size range (from 30 to $320 \mathrm{~nm}$ ), nearest neighbor extrapolations were performed to get $F_{\text {in }}$ values out of range, i.e. [10 nm, $30 \mathrm{~nm})$ and $(320 \mathrm{~nm}, 1000 \mathrm{~nm}$ ] as shown in Fig. 7. $k_{\text {shift }}$ shows positive values roughly on the right side of the peak of the particle size distributions and negative values on the left side. Positive $k_{\text {shift }}$ (at $D_{\mathrm{p}}$ in shaded areas) indicate condensation-induced increases in $n\left(D_{\mathrm{p}}\right)$ while negative $k_{\text {shift }}$ (at $D_{\mathrm{p}}$ in un-shaded areas) indicate condensation-induced decreases in $n\left(D_{\mathrm{p}}\right)$. Since the peaks of the $n_{\text {in }}\left(D_{\mathrm{p}}\right)$ and $n_{\mathrm{ex}}\left(D_{\mathrm{p}}\right)$ distributions appears at sizes smaller than $100 \mathrm{~nm}$, the condensation growth generally increases $n_{\text {in }}\left(D_{\mathrm{p}}\right)$ in the accumulation mode and reduces $n_{\text {in }}\left(D_{\mathrm{p}}\right)$ at the $D_{\mathrm{p}}$ of $30 \mathrm{~nm}$. 
a)

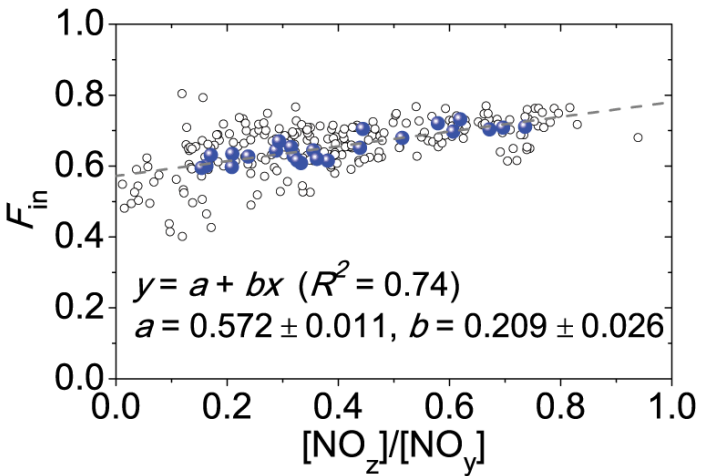

b)

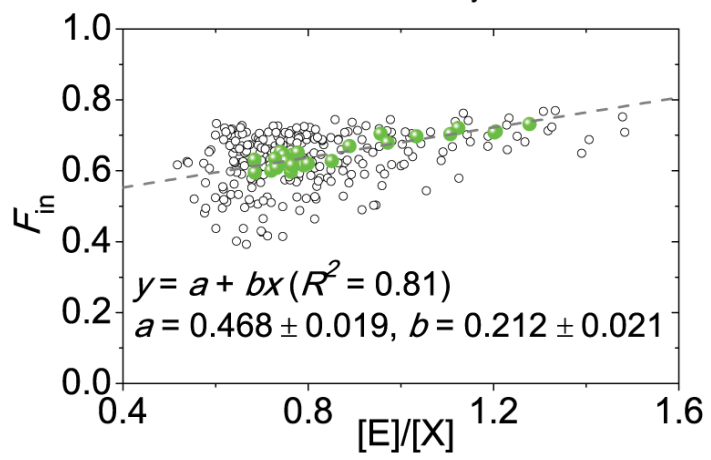

c)

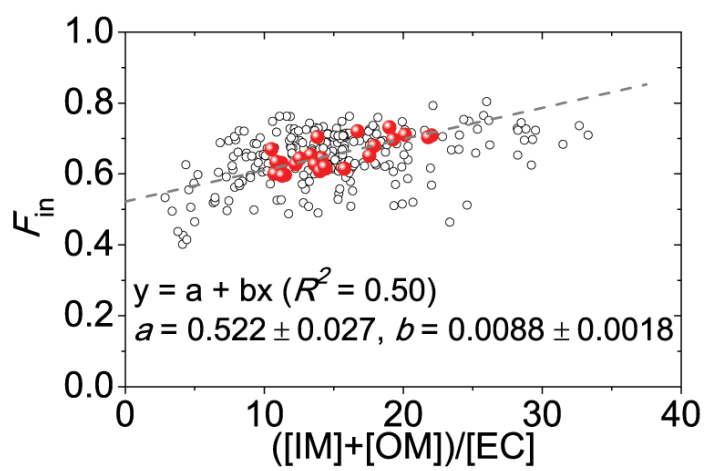

Fig. 8. Correlations between $F_{\text {in }}$ and (a) $\left[\mathrm{NO}_{\mathrm{z}}\right] /\left[\mathrm{NO}_{\mathrm{y}}\right]$, (b) $[\mathrm{E}] /[\mathrm{X}]$, and (c) $([\mathrm{IM}]+[\mathrm{OM}]) /[\mathrm{EC}]$. The open circles are measurement data with a time resolution of $1 \mathrm{~h}$; while the colored solid dots are average diurnal data. The average diurnal data can be linearly fitted by equation " $y=a+b x$ " (dashed line) with $R$ being the correlation coefficient.

\subsection{Size-resolved parameterizations of $F_{\text {in }}$}

Due to insufficient knowledge concerning the soot mixing state (and its temporal evolution) and the computational costs associated with explicit modeling of the mixing processes, it is still difficult to explicitly and accurately predict the variation of $F_{\text {in }}$ in regional/climate models. In an aging air mass, the change of soot mixing state is generally accompanied by the change of other indicators representing the air mass age. We suggest parameterizing the mixing state of soot by using these correlations. If the other indicators are easier to measure and model, such parameterizations might provide an alternative solution, narrowing down the differences between

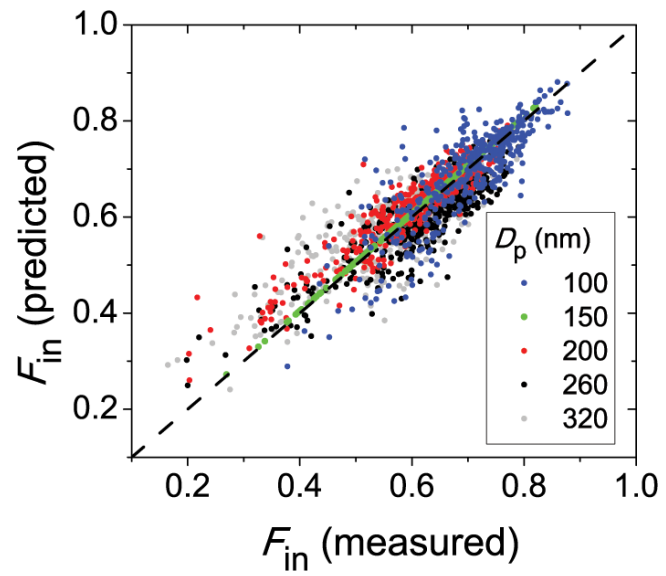

Fig. 9. Measured and predicted $F_{\text {in }}$ over $100 \mathrm{~nm}$ to $320 \mathrm{~nm}(2145$ data points). The dashed line represents the $1: 1$ line.

ambient and modeled soot mixing state without significant additional computational costs.

The proposed parameterization approach involves two steps to calculate $F_{\text {in }}$ from other indicators. First, the average diurnal values of $F_{\text {in }}$ and other parameters (as shown in Figs. 3 and 4) are adopted to calculate a linear fit, resulting in the parameterization Eqs. (10)-(12). The reason for using average values is to smooth out fluctuations which may greatly reduce the correlation coefficient $R$ and introduce large uncertainties into the fitting results. $F_{\text {in }}$ at certain diameter (i.e., $150 \mathrm{~nm}$ ) can be predicted by parameterization Eqs. (10)-(12). Figure 8a-c shows comparisons of $F_{\text {in }}$ at $150 \mathrm{~nm}$ with individual indicators, namely, $\left[\mathrm{NO}_{\mathrm{z}}\right] /\left[\mathrm{NO}_{\mathrm{y}}\right]$, $[\mathrm{E}] /[\mathrm{X}]$ and $([\mathrm{IM}]+[\mathrm{OM}]) /[\mathrm{EC}]$.

$F_{\text {in }}(150 \mathrm{~nm})=0.572+0.209 \frac{\left[\mathrm{NO}_{\mathrm{z}}\right]}{\left[\mathrm{NO}_{\mathrm{y}}\right]}$
$F_{\text {in }}(150 \mathrm{~nm})=0.468+0.212 \frac{[\mathrm{E}]}{[\mathrm{X}]}$
$F_{\text {in }}(150 \mathrm{~nm})=0.522+0.0088 \frac{[\mathrm{IM}]+[\mathrm{OM}]}{[\mathrm{EC}]}$

Second, we find that the size-resolved $F_{\text {in }}$ in the accumulation mode can be calculated by the following equation from $F_{\text {in }}$ at $150 \mathrm{~nm}$ :

$F_{\text {in }}\left(D_{\mathrm{p}}\right)=\left(a \log 10\left(D_{\mathrm{p}} / 1 \mathrm{~nm}\right)+b\right) F_{\text {in }}(150 \mathrm{~nm})$

where $a$ and $b$ are constant parameters.

Fitting Eq. (13) to the measured $F_{\text {in }}$ over the diameter range 100 to $320 \mathrm{~nm}$, we got $a=-0.353(-0.370,-0.336)$ (coefficients with $95 \%$ confidence bounds), $b=1.78$ (1.74, 1.82), and $R^{2}=0.80$. Figure 9 and Table 4 shows that Eq. (13) performs well in predicting the size-resolved $F_{\text {in }}$ over the size range between $100 \mathrm{~nm}$ and $320 \mathrm{~nm}$. There is no systematic underestimation (or overestimation) and the fitted slope $k$ is almost the same as the $1: 1$ line. Most variations of $F_{\text {in }}$, i.e., up to $77 \%$ can be predicted by the parameterization. 
Table 4. Correlation of measured and predicted $F_{\text {in }}$ (429 data points for individual size bins; 2145 data points for all size bins).

\begin{tabular}{ccccccc}
\hline & \multicolumn{5}{c}{$D_{\mathrm{p}}$} & \\
\cline { 2 - 5 } & $100 \mathrm{~nm}$ & $150 \mathrm{~nm}$ & $200 \mathrm{~nm}$ & $260 \mathrm{~nm}$ & $320 \mathrm{~nm}$ & all \\
\hline$k^{*}$ & $0.99 \pm 0.01$ & $1.01 \pm 0.00$ & $1.02 \pm 0.01$ & $0.96 \pm 0.01$ & $1.00 \pm 0.01$ & 0.99 \\
$R^{2}$ & 0.75 & 1.00 & 0.80 & 0.68 & 0.41 & 0.77 \\
\hline
\end{tabular}

$*_{k}$ is the fit parameter in the equation: $F_{\text {in }}$ (predicted) $=k F_{\text {in }}$ (measured).

This parameterization method requires caveats because considerable variability can be expected between different sites or even at a given site, like the scattered data shown in Figs. 8 and 9. To validate the parameterization methods, more measurements should be carried out in other environments.

\subsection{Coating thickness distribution}

In both the existing literature and the present study, the soot particles are often classified into two distinct groups (internally and externally mixed soot particles) by certain threshold core/shell ratios (e.g., $D_{\mathrm{p}, 300{ }^{\circ} \mathrm{C}} / D_{\mathrm{p}}$ ). However, the transition between the two groups in the atmosphere can be quite smooth, especially in aged air mass (Fig. 10, results at 13:00), and the threshold core/shell ratio should be considered as an arbitrary definition. Such "arbitrary" ratios (e.g., core/shell ratio $=0.5$ ) have also been used to distinguish different mixing states of soot particles in SP2 studies (e.g., Shiraiwa et al., 2007).

In our case, the use of different threshold ratios will change the absolute values of $F_{\text {in }}$ but leave the same/similar trends (see Fig. S3 for example). For a better description of the mixing state of soot particles, we suggest to consider the distribution concept, e.g., the distribution of the relative coating

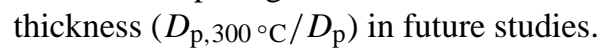

\section{Conclusions}

Analysis of VTDMA results from the megacity Beijing shows a pronounced diurnal variation of $F_{\text {in }}$ with different behaviors in the Aitken and accumulation modes. For accumulation mode particles, maxima of $F_{\text {in }}$ were observed at 12:00-13:00 LT, which can be explained by competing effects of physico-chemical conversion and direct emissions. The distinct diurnal cycles of $F_{\text {in }}$ of Aitken and accumulation mode particles are likely caused by faster growth of smaller Aitken mode particles.

To calculate the actual turnover rate of soot from external to internal mixture $\left(k_{\mathrm{ex} \rightarrow \mathrm{in}}\right)$, measurement data were analyzed by a conceptual model, which considered both direct emissions and the aging process. The analysis shows that the actual $k_{\mathrm{ex} \rightarrow \text { in }}$ has high values during daytime, i.e., a maximum around 11:00-15:00 LT, and low values during the night-time. Turnover rates reached values of $20-70 \% \mathrm{~h}^{-1}$

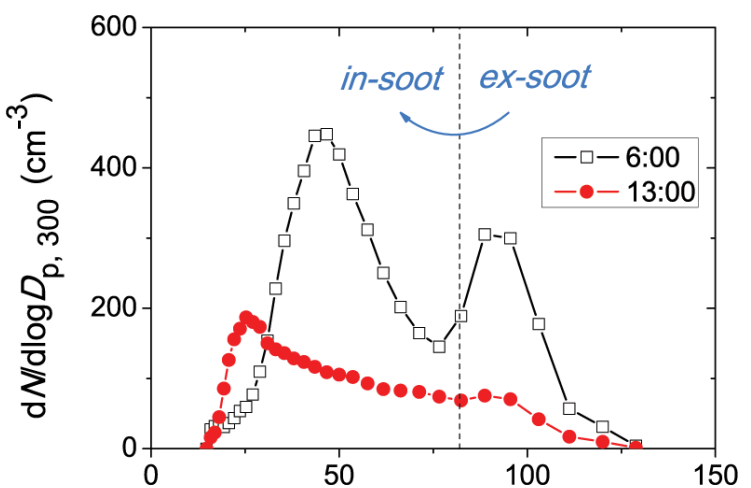

a)

$D_{\mathrm{p}, 300^{\circ} \mathrm{C}}(\mathrm{nm})$

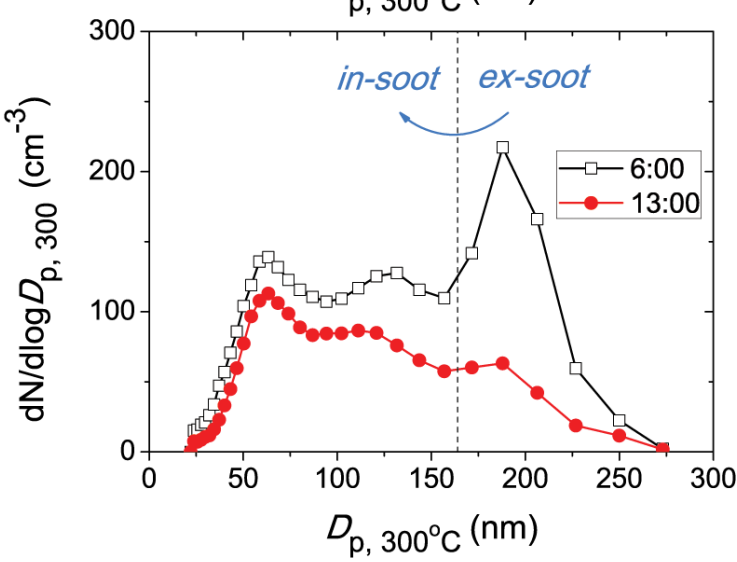

Fig. 10. Size distributions of nonvolatile residuals with initial diameter $D_{\mathrm{p}}$ of (a) $100 \mathrm{~nm}$ and (b) $200 \mathrm{~nm} . D_{\mathrm{p}, 300{ }^{\circ} \mathrm{C}}$ is the diameter of the nonvolatile residuals, i.e., particles after being heated at $300{ }^{\circ} \mathrm{C}$. The presence of particles with $D_{\mathrm{p}, 300^{\circ} \mathrm{C}}>D_{\mathrm{p}}$ is due to the transfer function of the DMA used for initial particle selections.

around mid-day, which implies that soot (NVP) particles are present to a large extent as internal mixtures by the time they leave the urban environment. This enables them to act as $\mathrm{CCN}$ and also facilitates their removal by wet deposition (Andreae and Rosenfeld, 2008). The cycle of $k_{\mathrm{ex} \rightarrow \text { in }}$ supports previous modeling results implying that the un-identified condensable vapors might have similar diurnal variations as sulfuric acid and other short life-time compounds produced by photochemistry. We also found that due to injection of fresh emissions, the "apparent" turnover rates derived from the variation in $F_{\text {in }}$ were much smaller than the actual $k_{\mathrm{ex} \rightarrow \text { in }}$. 
Table A1. Acronyms.

\begin{tabular}{ll}
\hline Symbol & Description \\
\hline AMS & Aerosol mass spectrometer \\
ATOFMS & Aerosol time-of-flight mass spectrometer \\
CAREBeijing & Campaign of air quality research in Beijing \\
CCN & Cloud condensation nuclei \\
DMA & Differential mobility analyzer \\
EC & Elemental carbon \\
GC-PID & Gas chromatography-photo ionization detector \\
OC & Organic carbon \\
PAN & Peroxyacetyl nitrates \\
PM & Particles of $1 \mu$ m or less in aerodynamic diameter \\
PM & Particles of $10 \mu$ m or less in aerodynamic diameter \\
SP2 & Single particle soot photometer \\
Soot (NVP) & Non-volatile-core containing particles, measured \\
& by the VTDMA, and taken as soot particles \\
VTDMA & Volatility tandem differential mobility analyzer \\
\hline
\end{tabular}

In this study, the calculated $k_{\mathrm{ex} \rightarrow \text { in }}$ might be subject to potential uncertainties due to: (1) the estimation of $\frac{1}{[\mathrm{EC}]}(\partial[\mathrm{EC}] / \partial t)_{\mathrm{Emis}}$ (relative emission rate of soot) and $\beta$ (number fraction of internally mixed soot particles in emissions); (2) the effect of transport process; and (3) the influence of particle growth and coagulation. To better understand the soot aging process, we suggest measuring $\beta$ in some emission studies, combining regional models to quantify the transport effects, and implementing aerosol dynamic models instead of the current conceptual model.

$F_{\text {in }}$ shows a similar diurnal course as the other air mass age indicators (e.g., $\left[\mathrm{NO}_{\mathrm{z}}\right] /\left[\mathrm{NO}_{\mathrm{y}}\right],[\mathrm{E}] /[\mathrm{X}]$ and $([\mathrm{IM}]+[\mathrm{OM}]) /[\mathrm{EC}])$, which are subject to competing effects between emissions and aging processes as well. The good agreement of their correlations can be expressed as a linear relationship. Given the difficulty of making direct measurements of soot mixing state $\left(F_{\text {in }}\right)$, these relationships might be of great practical value in regional/global-scale studies on the influence of the various direct and indirect soot aerosol effects on climate, as it provides an easily measured proxy that does not consume significant additional computing time. However, such parameterizations require caveats because considerable variability can be expected between different sites or even at a given site, like the scattered data shown in Figs. 8 and 9. To validate the parameterization methods, improve our understanding and refine the range of the fitting parameters, more measurements should be carried out in other environments. In addition, validation for particles larger than $320 \mathrm{~nm}$ needs to be performed in future studies.
Table A2. Symbols.

\begin{tabular}{|c|c|c|}
\hline Symbol & Unit* & Quantity \\
\hline$D$ & $\mathrm{~m}^{2} \mathrm{~s}^{-1}$ & Diffusion coefficient for species in air \\
\hline$D_{\mathrm{p}}$ & $\mathrm{nm}$ & Dry particle diameter \\
\hline$D_{\mathrm{p}, 300^{\circ} \mathrm{C}}$ & $\mathrm{nm}$ & $\begin{array}{l}\text { Particle diameter after being heated at } \\
300^{\circ} \mathrm{C} \text { in the VTDMA }\end{array}$ \\
\hline [E] & ppb & Concentration of ethylbenzene \\
\hline$[\mathrm{EC}]$ & $\mu \mathrm{g} \mathrm{m}^{-3}$ & Concentration of elemental carbon \\
\hline$F_{\text {in }}$ & & $\begin{array}{l}\text { Number fraction of internally mixed } \\
\text { soot particles (medium volatile } \\
\text { particles measured by VTDMA with } 82 \%> \\
D_{\mathrm{p}, 300{ }^{\circ} \mathrm{C} / D_{\mathrm{p}}>45 \% \text { ) in total soot particles }}\end{array}$ \\
\hline$f(K n, \alpha)$ & & $\begin{array}{l}\text { Correction due to non-continuum effects and } \\
\text { imperfect surface accommodation }\end{array}$ \\
\hline [IM] & $\mu \mathrm{g} \mathrm{m}^{-3}$ & $\begin{array}{l}{[\mathrm{IM}]=\left[\mathrm{NH}_{4}^{+}\right]+\left[\mathrm{NO}_{3}^{-}\right]+\left[\mathrm{SO}_{4}^{2-}\right]+\left[\mathrm{Cl}^{-}\right]} \\
\text {(inorganic mass in } \mathrm{PM}_{1} \text { measured by } \\
\text { aerosol mass spectrometer, AMS) }\end{array}$ \\
\hline$K n$ & & Knudsen number \\
\hline$k_{\mathrm{ex} \rightarrow \mathrm{in}}$ & $\mathrm{h}^{-1}$ & $\begin{array}{l}\text { Turnover rate of soot, the rate of conversion } \\
\text { of externally mixed to internally mixed soot }\end{array}$ \\
\hline$k_{\text {shift }}$ & $\mathrm{nm}^{-2}$ & $\begin{array}{l}\text { Parameter representing the rate of change } \\
\text { of particle number concentrations at certain } \\
\text { size bin due to the condensational growth }\end{array}$ \\
\hline$M$ & $\mathrm{~kg} \mathrm{~mol}^{-1}$ & Molecular weight \\
\hline$N_{\mathrm{CN}}$ & $\mathrm{cm}^{-3}$ & Number concentration of aerosol particles \\
\hline$N_{\mathrm{CCN}}$ & $\mathrm{cm}^{-3}$ & Number concentration of $\mathrm{CCN}$ \\
\hline$\left[\mathrm{NO}_{\mathrm{X}}\right]$ & $\mathrm{ppb}$ & Concentration of $\mathrm{NO}+\mathrm{NO}_{2}$ \\
\hline$\left[\mathrm{NO}_{\mathrm{y}}\right]$ & $\mathrm{ppb}$ & Concentration of total reactive nitrogen \\
\hline$\left[\mathrm{NO}_{\mathrm{z}}\right]$ & ppb & {$\left[\mathrm{NO}_{\mathrm{y}}\right]-\left[\mathrm{NO}_{\mathrm{x}}\right]$} \\
\hline$n_{\text {in }}$ & $\mathrm{cm}^{-3}$ & $\begin{array}{l}\text { Number concentration of internally mixed } \\
\text { soot particles }\end{array}$ \\
\hline$n_{\mathrm{ex}}$ & $\mathrm{cm}^{-3}$ & $\begin{array}{l}\text { Number concentration of externally mixed } \\
\text { soot particles }\end{array}$ \\
\hline$n_{\text {tot }}$ & $\mathrm{cm}^{-3}$ & Number concentration of total soot particles \\
\hline$[\mathrm{OM}]$ & $\mu \mathrm{g} \mathrm{m}^{-3}$ & $\begin{array}{l}\text { Mass concentration of organic matter } \\
\text { (in } \mathrm{PM}_{1} \text { measured by aerosol mass } \\
\text { spectrometer, AMS) }\end{array}$ \\
\hline$P$ & $\mathrm{~Pa}$ & $\begin{array}{l}\text { Supersaturated vapor pressure of } \\
\text { condensable species }\end{array}$ \\
\hline$R$ & $\mathrm{~J} \mathrm{~mol}^{-1} \mathrm{~K}^{-1}$ & Molar gas constant (unless specified) \\
\hline$S$ & $\%$ & Supersaturation of water vapor \\
\hline$T$ & $\mathrm{~K}$ & Kelvin temperature \\
\hline$t$ & $\mathrm{~s}$ & Time \\
\hline$[\mathrm{X}]$ & $\mathrm{ppb}$ & Concentration of $\mathrm{m}, \mathrm{p}$-xylene \\
\hline$\alpha$ & & Accommodation coefficient \\
\hline$\beta$ & & $\begin{array}{l}\text { Number fraction of internally mixed soot } \\
\text { particles in emissions }\end{array}$ \\
\hline$\sigma_{\mathrm{g}, \kappa}$ & & $\begin{array}{l}\text { Geometric standard deviation in a lognormal } \\
\kappa \text { distribution }\end{array}$ \\
\hline$\kappa$ & & Hygroscopicity parameter \\
\hline $\bar{\kappa}_{\mathrm{g}}$ & & $\begin{array}{l}\text { Geometric mean of } \kappa \text { in a lognormal } \\
\kappa \text { distribution }\end{array}$ \\
\hline$\lambda$ & $\mathrm{m}$ & $\begin{array}{l}\text { Mean free path of the condensable species } \\
\text { in air }\end{array}$ \\
\hline$\rho_{\mathrm{p}}$ & $\mathrm{kg} \mathrm{m}^{-3}$ & Particle density \\
\hline
\end{tabular}

* if not specified.
Supplementary material related to this article is available online at: http://www.atmos-chem-phys.net/12/ 4477/2012/acp-12-4477-2012-supplement.pdf. 
Acknowledgements. The CAREBeijing 2006 campaign was supported by the Beijing Council of Science and Technology (HB200504-6, HB200504-2). This study was supported by the Max Planck Society (MPG), the Leibniz Institute for Tropospheric Research (IfT), Peking University, and the University of Tokyo (UT). Hang Su's work was supported in part by MPG, the PanEuropean Gas-AeroSOls-climate interaction Study (No. 265148, PEGASOS) and the European integrated project on aerosol cloud climate and air quality interactions (No. 036833-2, EUCAARI). Y. Kondo and N. Takegawa were supported by the Ministry of Education, Culture, Sports, Science, and Technology (MEXT) and the global environment research fund of the Japanese Ministry of the Environment (A-0803 and A-1101). Thanks are owed to all the team members of CAREBeijing 2006 for support during the campaign. We acknowledge the referees for the constructive suggestions.

Edited by: D. Parrish

\section{References}

Andreae, M. O. and Gelencsér, A.: Black carbon or brown carbon? The nature of light-absorbing carbonaceous aerosols, Atmos. Chem. Phys., 6, 3131-3148, doi:10.5194/acp-6-3131-2006, 2006.

Andreae, M. O. and Rosenfeld, D.: Aerosol-cloudprecipitation interactions. Part 1 . The nature and sources of cloud-active aerosols, Earth-Sci. Rev., 89, 13-41, doi:10.1016/j.earscirev.2008.03.001, 2008.

Bergstrom, R. W., Pilewskie, P., Russell, P. B., Redemann, J., Bond, T. C., Quinn, P. K., and Sierau, B.: Spectral absorption properties of atmospheric aerosols, Atmos. Chem. Phys., 7, 5937-5943, doi:10.5194/acp-7-5937-2007, 2007.

Bond, T. C., Habib, G., and Bergstrom, R. W.: Limitations in the enhancement of visible light absorption due to mixing state, J. Geophys. Res., 111, D20211, doi:10.1029/2006JD007315, 2006.

Burtscher, H., Baltensperger, U., Bukowiecki, N., Cohn, P., Hüglin, C., Mohr, M., Matter, U., Nyeki, S., Schmatloch, V., Streit, N., and Weingartner, E.: Separation of volatile and non-volatile aerosol fractions by thermodesorption: instrumental development and applications, J. Aerosol Sci., 32, 427-442, doi:10.1016/s0021-8502(00)00089-6, 2001.

Calvert, J.: Hydrocarbon involvement in photochemical smog formation in Los Angeles atmosphere, Environ. Sci. Technol., 10, 256-262, 1976.

Cheng, Y. F., Eichler, H., Wiedensohler, A., Heintzenberg, J., Zhang, Y. H., Hu, M., Herrmann, H., Zeng, L. M., Liu, S., Gnauk, T., Brüggemann, E., and He, L. Y.: Mixing state of elemental carbon and non-light-absorbing aerosol components derived from in situ particle optical properties at Xinken in Pearl River Delta of China, J. Geophys. Res., 111, D20204, doi:10.1029/2005JD006929, 2006.

Cheng, Y. F., Wiedensohler, A., Eichler, H., Heintzenberg, J., Tesche, M., Ansmann, A., Wendisch, M., Su, H., Althausen, D., Herrmann, H., Gnauk, T., Brüggemann, E., Hu, M., and Zhang, Y. H.: Relative humidity dependence of aerosol optical properties and direct radiative forcing in the surface boundary layer at Xinken in Pearl River Delta of China: an observation based numerical study, Atmos. Environ., 42, 6373-6397, 2008a.
Cheng, Y. F., Wiedensohler, A., Eichler, H., Su, H., Gnauk, T., Brüggemann, E., Herrmann, H., Heintzenberg, J., Slanina, J., Tuch, T., Hu, M., and Zhang, Y. H.: Aerosol optical properties and related chemical apportionment at Xinken in Pearl River Delta of China, Atmos. Environ., 42, 6351-6372, 2008b.

Cheng, Y. F., Berghof, M., Garland, R. M., Wiedensohler, A., Wehner, B., Müller, T., Su, H., Zhang, Y. H., Achtert, P., Nowak, A., Pöschl, U., Zhu, T., Hu, M., and Zeng, L. M.: Influence of soot mixing state on aerosol light absorption and single scattering albedo during air mass aging at a polluted regional site in Northeastern China, J. Geophys. Res., 114, D00G10, doi:10.1029/2008jd010883, 2009.

Cooke, W. F. and Wilson, J. J. N.: A global black carbon aerosol model, J. Geophys. Res., 101, 19395-19409, 1996.

Cooke, W. F., Liousse, C., Cachier, H., and Feichter, J.: Construction of a $1^{\circ} \times 1^{\circ}$ fossil fuel emission data set for carbonaceous aerosol and implementation and radiative impactor in the ECHAM4 model, J. Geophys. Res., 104, 22137-22162, 1999.

Cooke, W. F., Ramaswamy, V., and Kasibhatla, P.: A general circulation model study of the global carbonaceous aerosol distribution, J. Geophys. Res., 107, 4279, doi:10.1029/2001JD001274, 2002.

Engler, C., Rose, D., Wehner, B., Wiedensohler, A., Brüggemann, E., Gnauk, T., Spindler, G., Tuch, T., and Birmili, W.: Size distributions of non-volatile particle residuals $\left(\mathrm{D}_{\mathrm{p}}<800 \mathrm{~nm}\right)$ at a rural site in Germany and relation to air mass origin, Atmos. Chem. Phys., 7, 5785-5802, doi:10.5194/acp-75785-2007, 2007.

Frey, A., Rose, D., Wehner, B., Müller, T., Cheng, Y., Wiedensohler, A., and Virkkula, A.: Application of the volatility-TDMA technique to determine the number size distribution and mass concentration of less volatile particles, Aerosol Sci. Tech., 42, 817-828, doi:10.1080/02786820802339595, 2008.

Garland, R. M., Yang, H., Schmid, O., Rose, D., Nowak, A., Achtert, P., Wiedensohler, A., Takegawa, N., Kita, K., Miyazaki, Y., Kondo, Y., Hu, M., Shao, M., Zeng, L. M., Zhang, Y. H., Andreae, M. O., and Pöschl, U.: Aerosol optical properties in a rural environment near the mega-city Guangzhou, China: implications for regional air pollution, radiative forcing and remote sensing, Atmos. Chem. Phys., 8, 5161-5186, doi:10.5194/acp-8-5161-2008, 2008.

Garland, R. M., Schmid, O., Nowak, A., Achtert, P., Wiedensohler, A., Gunthe, S. S., Takegawa, N., Kita, K., Kondo, Y., Hu, M., Shao, M., Zeng, L. M., Zhu, T., Andreae, M. O., and Pöschl, U.: Aerosol optical properties observed during Campaign of Air Quality Research in Beijing 2006 (CAREBeijing2006): Characteristic differences between the inflow and outflow of Beijing city air, J. Geophys. Res., 114, D00G04, doi:10.1029/2008jd010780, 2009.

Gunthe, S. S., Rose, D., Su, H., Garland, R. M., Achtert, P., Nowak, A., Wiedensohler, A., Kuwata, M., Takegawa, N., Kondo, Y., Hu, M., Shao, M., Zhu, T., Andreae, M. O., and Pöschl, U.: Cloud condensation nuclei $(\mathrm{CCN})$ from fresh and aged air pollution in the megacity region of Beijing, Atmos. Chem. Phys., 11, 1102311039, doi:10.5194/acp-11-11023-2011, 2011.

Hasegawa, S. and Ohta, S.: Some measurements of the mixing state of soot-containing particles at urban and non-urban sites, Atmos. Environ., 36, 3899-3908, 2002. 
Horvath, H.: Atmospheric light absorption - a review, Atmos. Environ., 27A, 293-317, 1993.

Ivleva, N. P., Messerer, A., Yang, X., Niessner, R., and Pöschl, U.: Raman microspectroscopic analysis of changes in the chemical structure and reactitivity of soot in a diesel exhaust aftertreatment model system, Environ. Sci. Technol., 41, 3702-3707, 2007.

Jacobson, M. Z.: Development and application of a new air pollution modeling system - II. Aerosol module structure and design, Atmos. Environ., 31, 131-144, doi:10.1016/13522310(96)00202-6, 1997.

Jacobson, M. Z.: A physically-based treatment of elemental carbon optics: implications for global direct forcing of aerosols, Geophys. Res. Lett., 27, 217-220, 2000.

Jacobson, M. Z.: Strong radiative heating due to the mixing state of black carbon in atmospheric aerosol, Nature, 409, 695-697, 2001.

Japar, S. M., Brachaczek, W. W., Gorse, R. A., Norbeck, J. M., and Pierson, W. R.: The contribution of elemental carbon to the optical properties of rural atmospheric aerosols, Atmos. Environ., 20, 1281-1289, 1986.

Katrinak, K. A., Rez, P., and Buseck, P. R.: Structural variations in individual carbonaceous particles from an urban aerosol, Environ. Sci. Technol., 26, 1967-1976, 1992.

Katrinak, K. A., Rez, P., Perkes, P. R., and Bueseck, P. R.: Fractal geometry of carbonaceous aggregates from an urban aerosol, Environ. Sci. Technol., 27, 539-547, 1993.

Koch, K.: Transport and direct radiative forcing of carbonaceous and sulphate aerosols in the GISS GCM, J. Geophys. Res., 106, 20311-20332, 2001.

Kondo, Y., Komazaki, Y., Miyazaki, Y., Moteki, N., Takegawa, N., Kodama, D., Deguchi, S., Nogami, M., Fukuda, M., Miyakawa, T., Morino, Y., Koike, M., Sakurai, H., and Ehara, K.: Temporal variations of elemental carbon in Tokyo, J. Geophys. Res., 111, D12205, doi:10.1029/2005jd006257, 2006.

Kondo, Y., Sahu, L., Kuwata, M., Miyazaki, Y., Takegawa, N., Moteki, N., Imaru, J., Han, S., Nakayama, T., Oanh, N. T. K., Hu, M., Kim, Y. J., and Kita, K.: Stabilization of the mass absorption cross section of black carbon for filter-based absorption photometry by the use of a heated inlet, Aerosol Sci. Tech., 43, 741-756, doi:10.1080/02786820902889879, 2009.

Kondo, Y., Sahu, L., Moteki, N., Khan, F., Takegawa, N., Liu, X., Koike, M., and Miyakawa, T.: Consistency and traceability of black carbon measurements made by laser-induced incandescence, thermal-optical transmittance, and filter-based photo-absorption techniques, Aerosol Sci. Tech., 45, 295-312, doi:10.1080/02786826.2010.533215, 2010.

Lesins, G., Chylek, P., and Lohman, U.: A study of internal and external mixing scenarios and its effect on aerosol optical properties and direct radiative forcing, J. Geophys. Res., 107, 4094, doi:10.1029/2001JD000973, 2002.

Lohmann, U., Feichter, J., Penner, J., and Leaitch, R.: Indirect effect of sulfate and carbonaceous aerosols: a mechanistic treatment, J. Geophys. Res., 105, 12193-12206, 2000.

Moffet, R. C. and Prather, K. A.: In-situ measurements of the mixing state and optical properties of soot with implications for radiative forcing estimates, P. Natl. Acad. Sci. USA, 106, 1187211877, doi:10.1073/pnas.0900040106, 2009.

Moteki, N., Kondo, Y., Miyazaki, Y., Takegawa, N., Komazaki, Y., Kurata, G., Shirai, T., Blake, D. R., Miyakawa, T., and Koike, M.:
Evolution of mixing state of black carbon particles: aircraft measurements over the Western Pacific in March 2004, Geophys. Res. Lett., 34, L11803, doi:10.1029/2006GL028943, 2007.

Novakov, T., Ramanathan, V., Hansen, J. E., Kirchstetter, T. W., Sato, M., Sinton, J. E., and Sathaye, J. A.: Large historical changes of fossil-fuel black carbon aerosols, Geophys. Res. Lett., 30, 1324, doi:10.1029/2002g1016345, 2003.

Orsini, D. A., Wiedensohler, A., and Covert, D. S.: Volatility measurements of atmospheric aerosols in the Mid and South Pacific using a Volatility-Tandem-Differential-Mobility-Analyzer, J. Aerosol Sci., 27, S53-S54, 1996.

O’Brien, J. M., Shepson, P. B., Wu, Q., Biesenthal, T., Bottenheim, J. W., Wiebe, H. A., Anlauf, K. G., and Brickell, P.: Production and distribution of organic nitrates, and their relationship to carbonyl compounds in an urban environment, Atmos. Environ., 31, 2059-2069, doi:10.1016/s1352-2310(97)80002-7, 1997.

Parrish, D. D., Hahn, C. J., Williams, E. J., Norton, R. B., Fehsenfeld, F. C., Singh, H. B., Shetter, J. D., Gandrud, B. W., and Ridley, B. A.: Indications of photochemical histories of pacific air masses from measurements of atmospheric trace species at point arena, california, J. Geophys. Res., 97, 15883-15901, doi:10.1029/92jd01242, 1992.

Petters, M. D. and Kreidenweis, S. M.: A single parameter representation of hygroscopic growth and cloud condensation nucleus activity, Atmos. Chem. Phys., 7, 1961-1971, doi:10.5194/acp-71961-2007, 2007.

Philippin, S., Wiedensohler, A., and Stratmann, F.: Measurements of non-volatile fractions of pollution aerosols with an eight-tube volatility tandem differential mobility analyzer (VTDMA-8), J. Aerosol Sci., 35, 185-203, 2004.

Pöschl, U.: Atmospheric aerosols: composition, transformation, climate and health effects, Angew. Chem. Int. Edit., 44, 7520-7540, doi:10.1002/anie.200501122, 2005.

Pöschl, U.: Gas-particle interactions of tropospheric aerosols: Kinetic and thermodynamic perspectives of multiphase chemical reactions, amorphous organic substances, and the activation of cloud condensation nuclei, Atmos. Res., 101, 562-573, doi:10.1016/j.atmosres.2010.12.018, 2011.

Pöschl, U., Martin, S. T., Sinha, B., Chen, Q., Gunthe, S. S., Huffman, J. A., Borrmann, S., Farmer, D. K., Garland, R. M., Helas, G., Jimenez, J. L., King, S. M., Manzi, A., Mikhailov, E., Pauliquevis, T., Petters, M. D., Prenni, A. J., Roldin, P., Rose, D., Schneider, J., Su, H., Zorn, S. R., Artaxo, P., and Andreae, M. O.: Rainforest aerosols as biogenic nuclei of clouds and precipitation in the Amazon, Science, 329, 1513-1516, doi:10.1126/science.1191056, 2010.

Riemer, N., Vogel, H., and Vogel, B.: Soot aging time scales in polluted regions during day and night, Atmos. Chem. Phys., 4, 1885-1893, doi:10.5194/acp-4-1885-2004, 2004.

Riemer, N., West, M., Zaveri, R., and Easter, R.: Estimating black carbon aging time-scales with a particle-resolved aerosol model, J. Aerosol Sci., 41, 143-158, doi:10.1016/j.jaerosci.2009.08.009, 2010.

Rose, D., Wehner, B., Ketzel, M., Engler, C., Voigtländer, J., Tuch, T., and Wiedensohler, A.: Atmospheric number size distributions of soot particles and estimation of emission factors, Atmos. Chem. Phys., 6, 1021-1031, doi:10.5194/acp-6-1021-2006, 2006. 
Rose, D., Gunthe, S. S., Mikhailov, E., Frank, G. P., Dusek, U., Andreae, M. O., and Pöschl, U.: Calibration and measurement uncertainties of a continuous-flow cloud condensation nuclei counter (DMT-CCNC): CCN activation of ammonium sulfate and sodium chloride aerosol particles in theory and experiment, Atmos. Chem. Phys., 8, 1153-1179, doi:10.5194/acp-8-11532008, 2008.

Rose, D., Gunthe, S. S., Su, H., Garland, R. M., Yang, H., Berghof, M., Cheng, Y. F., Wehner, B., Achtert, P., Nowak, A., Wiedensohler, A., Takegawa, N., Kondo, Y., Hu, M., Zhang, Y., Andreae, M. O., and Pöschl, U.: Cloud condensation nuclei in polluted air and biomass burning smoke near the mega-city Guangzhou, China - Part 2: Size-resolved aerosol chemical composition, diurnal cycles, and externally mixed weakly $\mathrm{CCN}$-active soot particles, Atmos. Chem. Phys., 11, 2817-2836, doi:10.5194/acp-112817-2011, 2011.

Rosen, H., Hansen, A. D. A., Gundel, L., and Novakov, T.: Identification of the optical absorbing component in urban aerosols, Appl. Optics, 17, 3859-3861, 1979.

Sadezky, A., Muckenhuber, H., Grothe, H., Niessner, R., and Pöschl, U.: Raman microspectroscopy of soot and related carbonaceous materials: spectral analysis and structural information, Carbon, 43, 1731-1742, doi:10.1016/j.carbon.2005.02.018, 2005.

Seinfeld, J. H. and Pandis, S. N.: Atmospheric Chemistry and Physics, from Air Pollution to Climate Change, Wiley, New York, 2006.

Shiraiwa, M., Kondo, Y., Moteki, N., Takegawa, N., Miyazaki, Y., and Blake, D. R.: Evolution of mixing state of black carbon in polluted air from Tokyo, Geophys. Res. Lett., 34, L16803, doi:10.1029/2007GL029819, 2007.

Shiraiwa, M., Kondo, Y., Moteki, N., Takegawa, N., Sahu, L. K., Takami, A., Hatakeyama, S., Yonemura, S., and Blake, D. R.: Radiative impact of mixing state of black carbon aerosol in Asian outflow, J. Geophys. Res., 113, D24210, doi:10.1029/2008jd010546, 2008.

Shiraiwa, M., Kondo, Y., Iwamoto, T., and Kita, K.: Amplification of light absorption of black carbon by organic coating, Aerosol Sci. Tech., 44, 46-54, doi:10.1080/02786820903357686, 2010.

Smith, D. M., Akhter, M. S., Jassim, J. A., Sergides, C. A., Welch, W. F., and Chughtai, A. R.: Studies of the stucture and reactivity of soot, Aerosol Sci. Tech., 45, 1397-1415, 1989.

Smith, M. H. and O'Dowd, C. D.: Observations of accumulation mode aerosol composition and soot carbon concentrations by means of a high-temperature volatility technique, J. Geophys. Res., 101, 19583-19591, doi:10.1029/95jd01750, 1996.

Stephens, M., Turner, N., and Sandberg, J.: Particle identification by laser-induced incandescence in a solid-state laser cavity, Appl. Optics, 42, 3726-3736, 2003.

Su, H., Cheng, Y. F., Cheng, P., Zhang, Y. H., Dong, S., Zeng, L. M., Wang, X., Slanina, J., Shao, M., and Wiedensohler, A.: Observation of nighttime nitrous acid (HONO) formation at a nonurban site during PRIDE-PRD2004 in China, Atmos. Environ., 42, 6219-6232, doi:10.1016/j.atmosenv.2008.04.006, 2008.
Su, H., Rose, D., Cheng, Y. F., Gunthe, S. S., Massling, A., Stock, M., Wiedensohler, A., Andreae, M. O., and Pöschl, U.: Hygroscopicity distribution concept for measurement data analysis and modeling of aerosol particle mixing state with regard to hygroscopic growth and CCN activation, Atmos. Chem. Phys., 10, 7489-7503, doi:10.5194/acp-10-7489-2010, 2010.

Takegawa, N., Miyakawa, T., Kondo, Y., Jimenez, J. L., Zhang, Q., Worsnop, D. R., and Fukuda, M.: Seasonal and diurnal variations of submicron organic aerosol in Tokyo observed using the Aerodyne serosol mass spectrometer, J. Geophys. Res., 111, D11206, doi:10.1029/2005JD006515, 2006.

Takegawa, N., Miyakawa, T., Watanabe, M., Kondo, Y., Miyazaki, Y., Han, S., Zhao, Y., van Pinxteren, D., Bruggemann, E., Gnauk, T., Herrmann, H., Xiao, R., Deng, Z., Hu, M., Zhu, T., and Zhang, Y.: Performance of an aerodyne aerosol mass spectrometer (AMS) during intensive campaigns in China in the summer of 2006, Aerosol Sci. Technol., 43, 189-204, 2009.

Tsigaridis, K. and Kanakidou, M.: Global modelling of secondary organic aerosol in the troposphere: a sensitivity analysis, Atmos. Chem. Phys., 3, 1849-1869, doi:10.5194/acp-3-1849-2003, 2003.

Wehner, B., Berghof, M., Cheng, Y. F., Achtert, P., Birmili, W., Nowak, A., Wiedensohler, A., Garland, R. M., Pöschl, U., $\mathrm{Hu}$, M., and Zhu, T.: Mixing state of nonvolatile aerosol particle fractions and comparison with light absorption in the polluted Beijing region, J. Geophys. Res., 114, D00G17, doi:10.1029/2008jd010923, 2009.

Wiedensohler, A., Cheng, Y. F., Nowak, A., Wehner, B., Achtert, P., Berghof, M., Birmili, W., Wu, Z. J., Hu, M., Zhu, T., Takegawa, N., Kita, K., Kondo, Y., Lou, S. R., Hofzumahaus, A., Holland, F., Wahner, A., Gunthe, S. S., Rose, D., Su, H., and Pöschl, U.: Rapid aerosol particle growth and increase of cloud condensation nucleus activity by secondary aerosol formation and condensation: a case study for regional air pollution in Northeastern China, J. Geophys. Res., 114, D00G08, doi:10.1029/2008jd010884, 2009.

Xie, X., Shao, M., Liu, Y., Lu, S., Chang, C.-C., and Chen, Z.-M.: Estimation of initial isoprene contribution to ozone formation potential in Beijing, China, Atmos. Environ., 42, 6000-6010, doi:10.1016/j.atmosenv.2008.03.035, 2008.

Zhou, Y., Wu, Y., Yang, L., Fu, L., He, K., Wang, S., Hao, J., Chen, J., and Li, C.: The impact of transportation control measures on emission reductions during the 2008 olympic games in Beijing, China, Atmos. Environ., 44, 285-293, doi:10.1016/j.atmosenv.2009.10.040, 2010. 